Illinois State University

ISU ReD: Research and eData

Theses and Dissertations

$11-11-2013$

\title{
Who Do You Play For?: Naming, Difference and the Creation of Scandal in Literature
}

Tristan Lipe

Illinois State University, talipe@ilstu.edu

Follow this and additional works at: https://ir.library.illinoisstate.edu/etd

Part of the English Language and Literature Commons

\section{Recommended Citation}

Lipe, Tristan, "Who Do You Play For?: Naming, Difference and the Creation of Scandal in Literature" (2013). Theses and Dissertations. 71.

https://ir.library.illinoisstate.edu/etd/71

This Thesis is brought to you for free and open access by ISU ReD: Research and eData. It has been accepted for inclusion in Theses and Dissertations by an authorized administrator of ISU ReD: Research and eData. For more information, please contact ISUReD@ilstu.edu. 


\title{
WHO DO YOU PLAY FOR?: NAMING, DIFFERENCE, AND THE CREATION OF SCANDAL IN LITERARY PRODUCTION
}

\author{
TRISTAN LIPE
}

78 Pages

December 2013

An exploration of how the creation of groups and interactions between groups impact people in the world. Beginning with an introduction that explores, specifically, how the creation of groups can function in the literary world when they are used as scandals. The introduction focuses on the rise of Poet, Kenneth Goldsmith and his use of Conceptualism to promote his brand. Following the introduction is a poetic exploration of groups and group conflict. It draws on social psychology, sociology as well as instances of violence partially resulting from rivalry between groups. 
WHO DO YOU PLAY FOR?: NAMING, DIFFERENCE,

AND THE CREATION OF SCANDAL

IN LITERARY PRODUCTION

TRISTAN LIPE

A Thesis Submitted in Partial

Fulfillment of the Requirements

for the Degree of

MASTERS OF SCIENCE

Department of English

ILLINOIS STATE UNIVERSITY

2013 


\section{Copyright 2013 Tristan Lipe}


WHO DO YOU PLAY FOR?: NAMING, DIFFERENCE,

AND THE CREATION OF SCANDAL

IN LITERARY PRODUCTION

TRISTAN LIPE

COMMITTEE MEMBERS:

Gabriel Gudding, Chair

Duriel E. Harris 


\section{ACKNOWLEDGEMENTS}

I would like to thank my wonderful wife (who became my wife during this crazy process) who is more responsible for this than I am. I would also like to thank my wonderful family and friends (who are really more like family) for all the support and guidance they have given me. I would

finally like to thank my great committee members and all my fellow students at ISU who have all given me so many gifts. If I have learned anything it is that I am because of all of you. Thank you.

T.L. 


\section{CONTENTS}

Page

ACKNOWLEDGEMENTS

i

CONTENTS

ii

INTRODUCTION

1

WHO DO YOU PLAY FOR? POEMS 22

$\begin{array}{ll}\text { REFERENCES } & 75\end{array}$

$\begin{array}{ll}\text { NOTES } & 77\end{array}$ 


\title{
INTRODUCTION
}

\begin{abstract}
...the definition of the writer (or artist, etc.) is an issue at stake in struggles in every literary (or artistic, etc.) field. In other words, the field of cultural production is the site of struggles in which what is at stake is the power to impose the dominant definition of the writer and therefore to delimit the population of those entitled to take part in the struggle to define the writer
\end{abstract}

Bourdieu 41-42

From familiar names like the Beats, to Dada, to less familiar names like the Futurists, literary groups have been a mainstay of the literary world. When groups exist during the same time period they often find themselves in conflict with one another, fighting over whose literary answer is superior. These fights play out in a public sphere and often bring attention and regard to the artists involved. However, when the named group strives to gain attention through its actions, the group becomes larger than the artists and the writing. When the group is created it is a scandal and the writing is of less consequence because its importance and relevance is measured by its relation to the named group. The name of the group becomes a brand and the brand becomes more significant than the writing. Kenneth Goldsmith uses this strategy to create a position for himself in the literary field. He names Conceptualism and turns it into a scandal that brings him attention and success. Writing should help readers share experiences and should allow readers to see across differences. When a literary group becomes a brand the opportunity for writing to have beneficial interaction with the reader is removed. Readers are 
duped into buying into the importance of the group and other writers are forced into playing the game as well.

[Naming/Branding]

By naming a group, artists create a label or a brand that builds recognition and the potential for a position in the literary field, sometimes even generating a new position. A writer occupies a position when he is recognized by other writers in the field. To have a position is to have validity as a writer. Without a position a writer cannot continue to exist in the literary world. Naming also serves to differentiate the group and its members from other artists through the brand.

To 'make one's name' [faire date] means making one's mark, achieving recognition (in both senses) of one's difference from other producers, especially the most consecrated of them; at the same time, it means creating a new position beyond the positions presently occupied, ahead of them, in the avant-garde... Hence the importance, in this struggle for life and survival, of the distinctive marks which, at best, aim to identify what are often the most superficial and most visible properties of a set of works or producers. Words - the names of schools or groups, proper names - are so important only because they make things. These distinctive signs produce existence in a world in which the only way to be is to be different, to 'make one's name,' either personally or as a group.

Bourdieu 106

Naming a group creates existence. Once a group is named, an artist without any position in the literary world has created a position. These types of groups exist as "pseudo-concepts, [and] practical classifying tools" that create differences by "naming them" (Bourdieu 106). The name is the group's brand. Difference is a byproduct of the existence of the groups and the group builds value by highlighting and exaggerating the difference (Bourdieu 106). They are superficial and create difference in order to appear unique and help the brand stand out. When named, the named group creates a disturbance in the art world. It is a scandal that draws attention and provokes other artist into denouncing and consecrating the group and establishing the brand. 
[Creating a Scandal]

Three criteria are necessary for an event, claim, or act to be considered a scandal: a transgression, someone who will publicize the transgression and an interested public (Adut 12). A transgression is an event, claim, or act that is considered unacceptable, inappropriate, and/or problematic to a public. A transgression "need not be real" for a scandal to exist as long as the supposed transgression generates "a negatively oriented interest or even curiosity from a public" (Adut 13). The presence of a public is crucial because often behaviors that become transgressions are tolerable in private. But, once introduced to the public the same behaviors become unacceptable. Though a transgression may be intentional, it is very likely that "nonliberal publics will in particular not require transgressive intent to see something as scandalous" (Adut 13). The nature of the artistic economy causes the literary world to be fairly conservative because the artists who occupy the positions that make up the artistic world want things to stay the same. Therefore, an act would not need to be purposefully transgressive to create a scandal.

Goldsmith's naming and continued marketing of Conceptualism is a transgression. Agents in the field of art (artists) attempt to keep and maintain their positions: "those in dominant positions operate essentially defensive strategies, designed to perpetuate the status quo by maintaining themselves and the principles on which their dominance is based" (Bourdieu 83). Naming the group, however, may not be enough to be a transgression. The name must be a threat to the established positions. To do that, Goldsmith markets Conceptualism into a brand. Critics recognize this: Seth Abramson said, "Conceptualism produces primarily a discussion about poets, not poetry-an ironic twist for a movement whose manifestos explicitly declare many of the unique generative capabilities of poets irrelevant" (Actuary Lit). Robert 
Archambeau says that "half of [his] friends in the little world of poetry expressed delight that the horrible careerist bastards [Conceptualists] were finally getting called out for their sins" (Archambeau). Thomas Brady of "Scarriet" goes as far as to say Goldsmith is not a Conceptualist: “Conceptualism, in Goldsmith's case...is a terrible misnomer (his emphasis) because of the way he represents Conceptualism (Scarriet). In an article on Harriet Blog Mark Nowak says that "Goldsmith identifies himself with his brand and tries to convince his audience that they should, no, need to, no, must buy into the spokesperson's product" (Harriet Blog). Perhaps the most extreme criticism is from Ted Berryman. He says that Kenneth Goldsmith is "subservient to the idea of conceptual art not because he cares about it, but because being so benefits him personally" (Internet Presence). He blatantly calls Goldsmith's use of Conceptualism a marketing ploy. By naming Conceptualism and continuing to market the brand, Goldsmith created a new position which other artists were forced to recognize. The combination of naming and then marketing of the brand constitutes the transgression.

The transgression then needs to be publicized in order to become a scandal. Simply put, "no publicity, no scandal" (Adut 19). The transgression can be publicized by an outside source or it may even be that "the publicizer [is] the author of [the] transgression already committed" (Adut 14). The publicizing can take place through the news media, through a public denouncement or claim or anyway, as long as the transgression reaches an interested audience. The publicity does not even "have to include new or true information to engender a scandal; it is sufficient that it generates negative and sustained interest" (Adut 15).

The public needs to be "a collectivity that has reasons to be interested in the event [transgression]. It may have a stake in reacting to the offender or, more often, in legitimating reaction taken in its name by authorities or opinion leaders" (Adut 16). If the public does not 
care enough to watch, the transgression will go away. The transgression will also go away if the public does not have a collective awareness. It is easy for an individual to turn a blind eye when he thinks others may not know of the transgression. The transgression gains publicity when each individual "knows and cannot pretend not to know the position of the others" (Adut 19). Though the public needs to have collective awareness, the public does not need to be interactive. A scandal does not "require a fully participating public; it is enough that the public simply watch" (Adut 16). Because of this, scandals "mostly consist of nonintimates of the transgressor - that is, those who can remain spectators to the event, those who are basically outsiders" (Adut 16). The majority of participants have little to no direct connection to the transgression but they are the ones who create the foundation of the scandal. The size of the public does not matter either; it just needs to be large enough to be a public. It does not matter if the transgression is exposed on purpose or by accident. Intent has no effect on the outcome.

Goldsmith publishes essays and open letters about conceptualism in major poetry publications so his essays were encountered by other writers and invested readers. He uses backhanded insults to provoke others and declare how interesting Conceptualism is. In Sentences on Conceptual Writing he says that Conceptual writing is "usually free from the dependence on the skill of the writer as a craftsman. It is the objective of the author who is concerned with uncreative writing to make her work mentally interesting to the reader," suggesting that other writing is not "mentally interesting" (Goldsmith). He goes on to claim that "when poetry starts to take on some of the characteristics, such as staking out utilitarian zones, it weakens its function as art" (Goldsmith). He claims that many writers cannot utilize new materials like Conceptualists can: "New materials are one of the great afflictions of contemporary writing. Some writers confuse new materials with new ideas. There is nothing 
worse than seeing art that wallows in gaudy baubles. The electronic writing landscape is littered with such failures. By and large most authors who are attracted to these materials are the ones who lack the stringency of mind that would enable them to use the materials well. It takes a good writer to use new materials and make them into a work of literature" (Goldsmith). In his introduction to the ploy that was the flarf v. Conceptualism fight, Flarf is Dionysus. Conceptual Writing is Apollo, Goldsmith says "why atomize, shatter, and splay language into nonsensical shards when you can hoard, store, mold, squeeze, shovel, soil, scrub, package, and cram the stuff into towers of words and castles of language with the stroke of the keyboard?" (Harriett Blog). Certainly one of the best comes from his discussion of so called "mainstream poetry." Goldsmith says "It's usually competent and fairly academic stuff that neither challenges nor offends anyone. It would be like, instead of filling up this museum with the likes of Mike Kelley, Kara Walker, Matthew Barney and Jenny Holzer, you plastered the walls with that strand of stillvigorous but utterly irrelevant academic figuration that haunts the ad pages of magazines like Art in America" (Goldsmith). These comments and more exist on an online archive, UbuWeb, where he can further display the transgression. The created "publicity...almost imposes the transgression on the audience" (Adut 20). Most viewers of the website will probably be nonintimates or at least have little investment in interacting, but through reading the essays and visiting the website they are an involved public. Goldsmith is Conceptualism's publicizer.

Finally, there needs to be a negatively oriented public. Goldsmith's essays, books and other publications generate a public. His claims provoke and excite other artists to create negativity. The negativity prompts other writers to publish essays about conceptualism, in many cases denouncing and criticizing it. In "Note Contra Conceptualism" Henry Gould said "the Conceptualists come across as purveyors of technical tricks and gimmicks, quack doctors, 
hustlers, promoters, [and] (very) used-car salesmen" (Gould). Ron Sillman thought he should experience pure joy since Poetry the magazine was "gradually catching up with Poetry the website in showing off American poetics in all its glorious diversity" by including some Flarf and Conceptual poetry (Sillman). However, he was not excited because he thought Kenneth Goldsmith was "right about one thing here: no one means a word of it. Or at least he doesn't" (Sillman). Amy King describes groups like Conceptualism as "high school cliques" (The Rumpus). She says to "Think think tanks that figure "us" out for us. In their equations, you're either obedient, an adherent, or expendable / inconsequential. You're in or you're out. With us or against us." (The Rumpus). She critiques Goldsmith's reaction to critique: "The reiteration of a 'Conceptual writers versus everyone else' mentality is a groove Kenneth Goldsmith also quickly retreats to when faced with substantial criticism, especially as the rewards are immediate in their systematized reductions. He turns critical challenge of his practices into capitalist publicity, in the form of sensational headlines that are easy to remember and dependent on our own elementary fears of not fitting in" (The Rumpus). Calvin Bedient writes in his critique of Conceptualism, Against Conceptualism: Defending Poetry of Affect, "As for conceptual writing, its focus is not on truth either, but on the archivalism of copying and compilation, the mirroring (direct or crazy) of already published texts, as averred by its able exponent, Kenneth Goldsmith" (Boston Review). He goes on to say that "Conceptual writing is ruin piled on ruin" and "Conceptualism is a swampland of derivative texts, dishonored texts adopted for the sake of recycling, not as a nutrient to memory" (Boston Review). Even without the essays, it is likely that the public is invested enough and negatively oriented since other writers want to defend their positions and prevent the establishment of new positions. Other writers want to maintain the status quo, which is their interest and stake in Conceptualism. Conceptualism is a transgression, 
Goldsmith is its publicizer and it has a negatively oriented public. It meets all three criteria of a scandal.

[Staying Around]

When a group is denounced it becomes, at the same time, affirmed and established in its position. It is because "polemics imply a form of recognition; adversaries whom one would prefer to destroy by ignoring them cannot be combated without consecrating them" (Bourdieu 42). A transgression as a provocation is likely to induce denouncement because of the need for writers to defend their positions.

A scandal can end up increasing the status of the offender, and we may not want that. Esse est percipi. To be is to be recognized. Being noticed by a multitude for a disruptive act is even better, and a public denunciation by a high-status actor risks establishing the transgressor on a par with the denouncer by a negative consecration. It is thus not surprising that many transgressors seek to be denounced. They may well anticipate that the negative glory with which they will be crowned will trump the sanctions that they will receive

Adut 231

Goldsmith uses this exact strategy to cement his position. He uses his essays to provoke other poets into denouncing him. He also denounces other poets so they will, in turn, denounce him. He helps to manufacture a literary fight with flarf that consecrates both groups. He calls flarf "Dionysus to conceptual writing's Apollo" (Goldsmith). He imposes the fight on the public, and flarf, by declaring that everyone must "choose your position" in the battle between the two movements (Goldsmith). Groups in opposition reinforce each other the more publicly they fight.

The presence of competing groups is common because positions are codependent. No writer or position exists on an island, free from the other positions in the field. Each position "even the dominant one, depends of its very existence...on the other positions constituting the field" (Bourdieu 30). They exist together in a sort of artistic symbiosis. No matter how much or 
how little power and prestige a position has, its existence has an effect on the other positions in the field. The actions of each participant, individual or group, have an impact on every other participant. Goldsmith and conceptualism need the opposing position, flarf, to increase their success. Their mutual consecration is identified in an article from the Wall Street Journal: "a sign that further establishes flarf's literary cred, practitioners of a rival poetry movement called 'conceptual poetry' are now taking on the flarfists" (Naik). The recognition of the conflict serves Goldsmith's purpose by growing the original scandal into something that is not just about conceptualism, but also legitimacy. The article about both groups furthers their audience and creates even more attention. As a result, flarf denounces conceptualism, further consecrating it, in a cycle of consecration where both sides entrench themselves through the attention they gain. Plus, each reinforces the scandal by serving as a negatively oriented public.

To be successful in the art world agents often must build symbolic capital because it is so difficult to directly gain economic capital (money). Symbolic capital is prestige, regard and recognition. Symbolic capital is the primary currency because it is nearly impossible to gain economic capital directly. If they build up enough symbolic capital they are able to distinguish themselves and occupy the dominant positions which ensure long term economic profits. What is most at stake in literary struggles is "the monopoly of literary legitimacy...the monopoly of the power to say with authority who are authorized to call themselves writers...the power to consecrate producers or products" and ultimately those in the dominant position get to decide who and what belongs (Bourdieu 42). The field is in constant flux of new writers attempting to become consecrated and old(er) writers who want to defend and maintain their position as the dominant ones. 
Symbolic capital is the currency of the art world because its economy is the inverse of most other economies. It is an "upside-down economic world" (Bourdieu 40). Artists cannot depend on short-term economic gains or economic profit at all. The value of the product depends on the reputation of the producer and not necessarily the product itself.

\begin{abstract}
The economy of practices is base, as in a generalized game of 'loser wins,' on a systematic inversion of the fundamental principles of all ordinary economies: that of business (it [art economy] excludes the pursuit of profit and does not guarantee any sort of correspondence between investments and monetary gains), that of institutionalized cultural authority (the absence of any academic training or consecration may be considered a virtue).
\end{abstract}

Bourdieu 39

The literary world has established "an anti-economic economy based on the refusal of commerce and 'the commercial' and, more precisely, on the renunciation of short-term economic profits...and on recognition solely of symbolic, long-term profits (but which are ultimately reconvertible into economic profits)" (Bourdieu 54). Artists instead strive to build a reputation and gain recognition. One way in which they increase their prestige is by "hav[ing] an interest in disinterestedness" (Bourdieu 40). Artists will act as though they do not care about the value of their work because if they do it will expose an interest in economic gain. The idea is to be considered cool and unconcerned so that others will think you and, by extension, your works have value. These conditions induce "a pursuit of the riskiest positions in the intellectual and artistic avant-garde, and also for the capacity to remain there over a long period without economic compensation" (Bourdieu 40). If an artist is able to obtain or create one of those positions he will have an increased chance at economic profits.

[Why Scandal] 
In the art world, scandals often come as provocations. They can come about through "communicating one's own transgression to a public or by committing it in front of a public" and can be communicated either knowingly or unknowingly (Adut 225).

The art world provides a most propitious setting for public provocation. A scandal is an emotional affair; so is art. They are both public: however personal, art is typically destined to an audience composed of nonintimates [non family/friends]. But consequential art scandals require that people notice the transgressive work [or statements] and that opinion leaders bother to denounce it

Adut 225

Scandals play on people's emotions, stirring them up and drawing out reactions. The attention generated from a scandal can then lead to an increase in capital and increase in consecration of the artist.

Goldsmith uses scandal because it is a quick and fairly easy way for an artist to create attention. Scandals are "usually not single events but episodes" so they ensure that the artist(s) involved will foster attention over a sustained period of time (Adut 12). Sustained attention translates into long term capital. Scandal comes with an audience so readers are guaranteed. Also, scandals do not require sustained effort from the transgressor. Once the transgression is made, the transgressor can become an observer if he chooses.

Scandals do come with risks though. They can tarnish and damage the reputation or name of those involved: "there is such a thing as bad publicity: reputations are often irrevocably, unjustly ruined in scandals" (Adut 30). However, there is benefit to the high risk factor of scandal which is that high risk often leads to higher rewards. Artists take on "the riskiest investments" because they are "very often the most profitable symbolically" (Bourdieu 68). If an artist does not have a position he stands to lose little if his reputation is tarnished 
because there is little reputation to begin with. If the scandal pays off, the artist stands to gain increased attention and a quick route to symbolic capital.

Also, using naming mediates the risk for the transgressor because naming in the art world is a common practice. There have been the Futurists, Dada, Surrealism, Cubism, Suprematism, and many more groups that have established a name. The repetition of the same type of scandal creates the conditions where "a subsequent one [scandal] with similar content or denouncee [is] easier to break, and a rapid succession of such events will end up making us blasé...the more it is routinized, the more scandal will be revelatory of the world in which it erupts" (Adut 36). Using the same technique makes the scandal easier to break and the audience more indifferent to the negative aspects of it, all without losing the level of negative attention needed to sustain it.

Artists must hide any interest in economic gain. If an artist shows interest in economic gain he risks losing symbolic capital which would damage or destroy his position.

Producers and vendors of cultural goods who 'go commercial' condemn themselves, and not only from an ethical or aesthetic point of view, because they deprive themselves of the opportunities open to those who can recognize the specific demands of this universe and who, by concealing from themselves and others the interests at stake in their practice, obtain the means of deriving profits from disinterestedness

Bourdieu 75

Commercial interests stigmatize an artist as "impure" and lead to a loss of symbolic capital. Goldsmith preaches the same idea of purity when discussing UbuWeb. He says that what is most important is that UbuWeb is free and is "an absolutely clean space with no ulterior motives" (Archinect). He denies having any other (impure) motives other than the desire to distribute poetry “because it's [UbuWeb] based on love and passion. It [UbuWeb] has nothing to do with money" (Archinect). He makes these claims about purity despite the fact that his name is 
interlocked with the website and he gains recognition and symbolic capital for it. Just like Conceptualism, UbuWeb creates recognition and capital as a named thing. He goes on to rail against the possibility of Google creating a competitive website because if Google were to do it there would be "ulterior motives there... [and] they're not doing it to benefit humanity" (Archinect). Goldsmith does not get permission from authors to post their work because, as he claims, contracts would be impure and suggest a desire for money.

Goldsmith also uses denial as a way to bring value to his own work: "In uncreative writing [conceptualism] the idea or concept is the most important aspect of the work. When an author uses uncreative form of writing, it means that all of the planning and decisions are made beforehand and the execution is a perfunctory affair" (Goldsmith). Goldsmith denounces the actual art object in favor of the "concept" of the work. He fills the role of uncaring artist to try to bring value to the work. This is a disavowal that only works because he is pretending to not be doing what he is actually doing which is sell himself as a brand (Bourdieu 74). He uses the notion of pure intentions and denial as a wall between him and the benefit he gains.

Since the only "legitimate capital" is "'prestige' or 'authority,," artists need a way to convert the symbolic capital to economic capital without exposing their true intentions. Naming and labeling is a means of generating economic capital through reconverting symbolic capital.

\footnotetext{
For the author, the critic, the art dealer, the publisher or the theatre manager, the only legitimate accumulation consists in making a name for oneself, a known, recognized name, a capital of consecration implying a power to consecrate objects (with a trademark or signature) or persons (through publication, exhibition, etc.) and therefore to give value, and to appropriate the profits from this operation.
}

Bourdieu 75

The naming scandal allows the artist to give value to the art objects and "appropriate the profits" without being exposed as doing so (Bourdieu 75). Naming and branding act as a 
commercial smoke screen. Attention from the scandal is directed to the brand rather than the individual while the individual gets to reap the rewards. Branding is a way to create easy recognition to the consumer. A lay person is more likely to have some awareness of Dada over Tristan Tzara or Hugo Ball. The naming allows the artist to claim to have pure intentions even though they use a commercial strategy. It keeps any interest in interest concealed behind the claim that the artist works for the group, not himself. The scandal brings success and fame by spreading the name of the transgressor and/or the group.

The exact scenario played out with the "Mapplethorpe" scandal. The director of an arts center in Cincinnati was arraigned for public obscenity for displaying a photographer's sadomasochistic images. The trial concluded and determined that the images were art (based on the testimony of other, consecrated "art experts") and the price of the portfolio rose ten times what it was before the trial (Adut 286).

[Consequences of Groups]

The creation of a group is a means to generate and accumulate symbolic capital. When literary groups find themselves, as they often do, in opposition of one another, (i.e. the Futurists and Dada, conceptualism and flarf) the process "tends to consecrate and underscore the critical differences" (Bourdieu 67). Highlighting difference produces an othering effect. By stating that "this group exists" one not only creates the group, but creates its opposite. When a group is formed it really creates two groups: the individuals that are members of the group (ingroup) and the individuals who are not members of the group (outgroup). Coming into contact with a group a person is forced to consider, am I a member of this group or not. When groups are involved in conflict situations (such as literary fights) "individuals evaluate their groups more positively, show stronger affective attachment to the group, and are more willing to make costly 
contributions to enhance the group's welfare, compared to nonconflict settings" (Benard 107108). This effect is called ingroup bias. Ingroup bias fuels misunderstanding and misrecognition between groups and the effect of ingroup bias is amplified when there is a prize at stake.

In the literary world "the struggle" for recognition is a source of constant competition and conflict (Bourdieu 34). Recognition is the prize that amplifies the effects of ingroup bias. Competition between the groups leads them to be more normalized as well.

[P]erceived threat of outgroup competition generates strong affective and normative responses as well as instrumental concerns for the ingroup. That is, because individuals have emotional ties to their groups, threats to the group provoke emotional reactions. And because individuals see their groups in normative terms (i.e. we "ought" to outperform other groups), threats to the group motivate strong reactions because they violate individuals' sense of norm order of intergroup relations

Benard 111

The competing groups increase the intensity of each group's dedication and reinforce normative thinking. The tendency to "provoke emotional reactions" feeds the cycle of argumentation. Each reaction provokes a new reaction and increases the emotional level and expands the scandal. Unlike scandals though, for normative thinking and ingroup bias to occur it is necessary for each group to be actively participating. The presence of conflicting goals is not enough to motivate the increased ingroup bias.

Interactions between groups are likely to come with strong emotions. Strong emotions lead to stronger biases. When emotions are high people in different groups think about each other in empathetic ways. To limit biased thinking triggered by empathy people need to think with perspective taking. Adam Galinsky, Debra Gilin and William Maddux explore the differences between empathy and perspective taking in their article, Using Both Your Head and Your Heart: The Role of Perspective Taking and Empathy in Resolving Social Conflict. The difference between empathy and perspective taking is that "perspective taking is primarily a cognitive ability, [and] 
empathy is primarily an affective state of concern for others...Empathy does not correlate with the same constellation of personality characteristics as perspective taking" (Galinsky et. al. 107). They explored how likely subjects were to retaliate in a war game situation when primed with empathy or perspective taking. For the purposes of the game, "there [were] two roads to success...First; one potentially winning strategy is to disarm fewer weapons than one's adversary and then attack. Second, if neither player attacked in the 10 rounds of a game, 'peace' was declared" (Galinsky et. al. 112). When empathy was high between the participants "there was more retaliation" and "those higher on perspective taking not only disarmed their own arsenals to a greater extent but also were able to convince their opponents to do the same and thereby create joint gain" (Galinsky et. al. 112). The empathizers would get caught in "spirals of escalating conflict involving attack and counterattack" and perspective takers were able to better understand their counterparts and appreciate the other's thought process (Galinsky et. al. 112). Literary groups in conflict find themselves in the same type of spiraling, retaliation based, situations because they get caught up in the emotions of competition.

The presence of an outgroup causes the members of the ingroup to become more group-centric. They become more inwardly focused and less conscious of things outside the group. With rivalry between groups the tendency is for "people to become more cooperative with ingroup members, to regard one another as allies, and to put the needs of the group over the needs of the self" (Mead \& Maner 572). Group members become further entrenched the in their dedication and ingroup bias.

Group formation also influences people's ability to make judgments. Theresa DiDonato, Johannes Ullrich and Joachim Krueger identify three typical characteristics of group interaction: intergroup differentiation, ingroup favoritism, and differential accuracy. Intergroup 
differentiation occurs when "people perceive groups as different when they are similar," ingroup favoritism is when group members "attribute more positive characteristics to groups to which they belong than to groups which they do not belong [ingroup bias]," and differential accuracy is when people's "perceptions of ingroups tend to be more accurate than their perceptions of outgroups" (DiDonato et. al. 66). Group members key in on differences between groups while ignoring similarities. Though they may be able to understand their ingroup, their biases skew their perceptions about other groups.

The creation of the named literary group (the scandal) and the fight that may follow are distractions from the actual effects of the work. As Goldsmith said, the concept is most important in conceptualism, so there is no focus on what the work can do for the reader. Russian formalist Viktor Shklovsky also believed that the work itself is not important but he recognized the importance of ethical affects. For Shklovsky "Art is a way of experiencing the making of a thing, but the thing made in art is not important" (his emphasis) (Robinson 89). Art should restore sensation and thinking to life. The value of the poem "is the poem as psychological effect" and not as an object (Robinson 95). Douglas Robinson theorizes that people can connect through what he terms "collective proprioception" where "the boundaries between the self and the other, the own and the alien, the familiar and the strange are policed" (Robinson 109). He discusses a "'proprioception of thought" which "is in a sense an attempt to step cognitively outside the group, to analyze ideosomatic regulation from an imaginary position above or beyond the group" (Robinson 110). What Robinson is talking about is essentially perspective taking. He is talking about stepping out of the group and to a place where we can see the other. This is the potential of poetry that is thwarted by scandal and concept. When the concept or the name is featured, the focus is on the poem as an object, rather than what it does. 
What should be important is the psychological effect that the poem has on the reader and how it can help others.

A Poet should not ignore ethical affect. Naming a group distracts from ethical affect and misleads an audience into difference focused thinking and bias. Poems should create opportunities for perspective takings so those who encounter it can gain a better understanding of the other. In "Some Notes Toward a Poetics" Lyn Hejinian proposes that a poem's function is to create space for encounter between the author and reader. The work should create a "guest/host relationship" that is dependent on the "co-existence" of both the guest and host (Hejinian 109-110). It is an equally weighted relationship and important that "the guest/host encounter creates a space of appearance...for 'the sharing of words and deeds'"' (Hejinian 111). The poem can be the location for sharing perspectives but that opportunity is destroyed when it is surrounded by the bias and distraction as well as on difference that is generated by the named group scandal.

With a named group, regardless of what the writing is about, the scandal is always looming. It creates a focus on ideologies and prevents readers from engaging in new ways of seeing. Goldsmith even claims that uncreative writing does not attempt to create anything new. He says that he "want[s] to take text[s] that have already been written and simply rewrite them and transcribe them without changing anything - claim them as my own simply by the act of retyping say a day's copy of the New York Times. So that it becomes my own and simply republishing it as that" (Archinect). Conceptualism makes no effort to estrange or create anything new but merely redoing what has already been made. Without estrangement readers will not engage with the work in a cognitive way and will have either an emotional interaction or no interaction at all. Either way, they are not pushed to break bias or change their thinking. His 
theories of uncreative writing merely reinforce pre-existing perceptions. According to Goldsmith, when a writer "uses a conceptual form of writing, it means that all of the planning and decisions are made beforehand and the execution is a perfunctory affair. The idea becomes a machine that makes the text. This kind of writing is not theoretical or illustrative of theories; it is intuitive, it is involved with all types of mental processes and it is purposeless" (Goldsmith). Purposeless writing keeps attention on the scandal and not on the work.

To help people change perception and experience perspective taking, poetry should be characterized by estrangement. "Estrangement is a term signifying a specific way of perceiving or realizing an already automatized phenomenon" (Robinson 79). To estrange is to challenge the reader to break their pre-existing perceptions. In the words of Viktor Shklovsky: "'in order to restore to us the perception of life, to make a stone stony, there exists that which we call art'" and "'only the creation of new forms of art can restore to man sensation of the world, can resurrect things and kill pessimism"' (Hejinian 115). Just like perspective taking, it requires cognitive interaction. It demands cognitive engagement from the reader so the reader can recontextualize something familiar through the unfamiliar whereas scandal requires only mindless observation. With estrangement the poem acts as a mechanism for the reader to engage in perspective taking. Through perspective taking people can have the opportunity to see the common spaces between others and not focus as much on difference. Estrangement does not exclude emotional interaction but requires cognitive engagement to increases the possibility of perspective taking.

Bias is a common characteristic of "groupthink" (Sawyer 66). Groupthink is a mindset that makes people believe the group is smarter or better when the individual is actually better. It occurs in the "all-too-common situations where a team of smart people ends up doing 
something dumber than they would have done if they had been working on their own" (Sawyer 66). There is an "illusion of group effectiveness" that results in over confidence in one's own group (Sawyer 66). Studies have shown that people often report that their group performed better on a task than they did individually. They do not believe that they were better as individuals and will "say that the group helped them - even though the researchers have hard numbers that prove otherwise" (Sawyer 66). Groupthink arises when group members share too much familiarity and "tacit knowledge" (Sawyer 66). When a group contains members who all share the same knowledge and language, they communicate in the ways that are already established by that knowledge and do not move outside the realm of the automatic thinking.

Groups need diversity to make things new and to avoid group think because "if your group is too homogeneous, it will be less creative" (Sawyer 131). The diverse group's ideas can be "better than what anyone [individual] could have developed alone" (Sawyer 14). Diverse groups will not share entirely common language so "they [are] forced to use analogies to develop new conceptual combinations" and break their common ways of doing things (Sawyer 131). In diverse collaborative groups, people can "play off one another" and create a cycle of creative, new ideas rather than a cycle of old ideologies (Sawyer 14). All of the effects of a naming scandal prevent groups from becoming diverse in the ways necessary to really be creative. Because groups like Conceptualism depend on their ideologies they have little or no interest in diversity. They want to expand their way of thinking rather than develop new ways of thinking. They look to bring others to their side and not see how other perspectives can be beneficial.

Ingroups and outgroups exist as binary oppositions. These types of "conventional 'hegemonic' oppositional theories greatly restrict people's actions by establishing binary 
categories between dominant and subordinate groups and by demanding an internal consistency that eventually fractures resistance movements from within" (Keating 45). Having binary based knowledge systems "reinforce[s] dominant/subordinate worldviews and restrictive forms of thinking that define difference as deviation from a single norm" (Keating 6). Creation of binaries reinforces difference based and prejudiced thinking. Instead of reinforcing difference, writing should focus on what AnaLouise Keating refers to as the "threshold" spaces (Keating 2). The threshold spaces exist between the binaries and help people see across to the other side. To navigate the threshold space is to navigate "'betwixt and between' worlds to establish new connections among apparently different peoples" (Keating 2). Using estrangement in writing to help create perspective taking opportunities can bring readers into and across the threshold spaces. It can allow for groups to overcome their bias and break down binary oppositions.

When the group acts out and cries for attention, the group does a disservice to all lovers of writing and reinforces binary thinking. They focus on personal gain rather than helping people gain perspective and reach through to the other's side. If we cannot ignore these groups then they will continue to hold literature back and stifle new writers. If we are to limit the instances of literary scandals, new writers need other ways to gain positions. Literary groups can still bring about new positions for writers but can do so in the right way if they focus more on diversity and creativity and avoid getting caught up in petty fights. This is not a simple task though. As long as the attention continues to go to the playground scuffles (like flarf and conceptualism) the cycle of consecration will continue. 
WHO DO YOU PLAY FOR?

POEMS

When listening to the interview, take the perspective of the person being interviewed. Imagine what it would be like to be this person. That is try to imagine what you would feel and think if you were that person. Try to go through the day in the life of this person as if you were that person. In your mind's eye visualize clearly and vividly how it would feel to be that person. Try not to concern yourself with attending to all the information presented. Just imagine what you would feel if you were that person going through his day. 


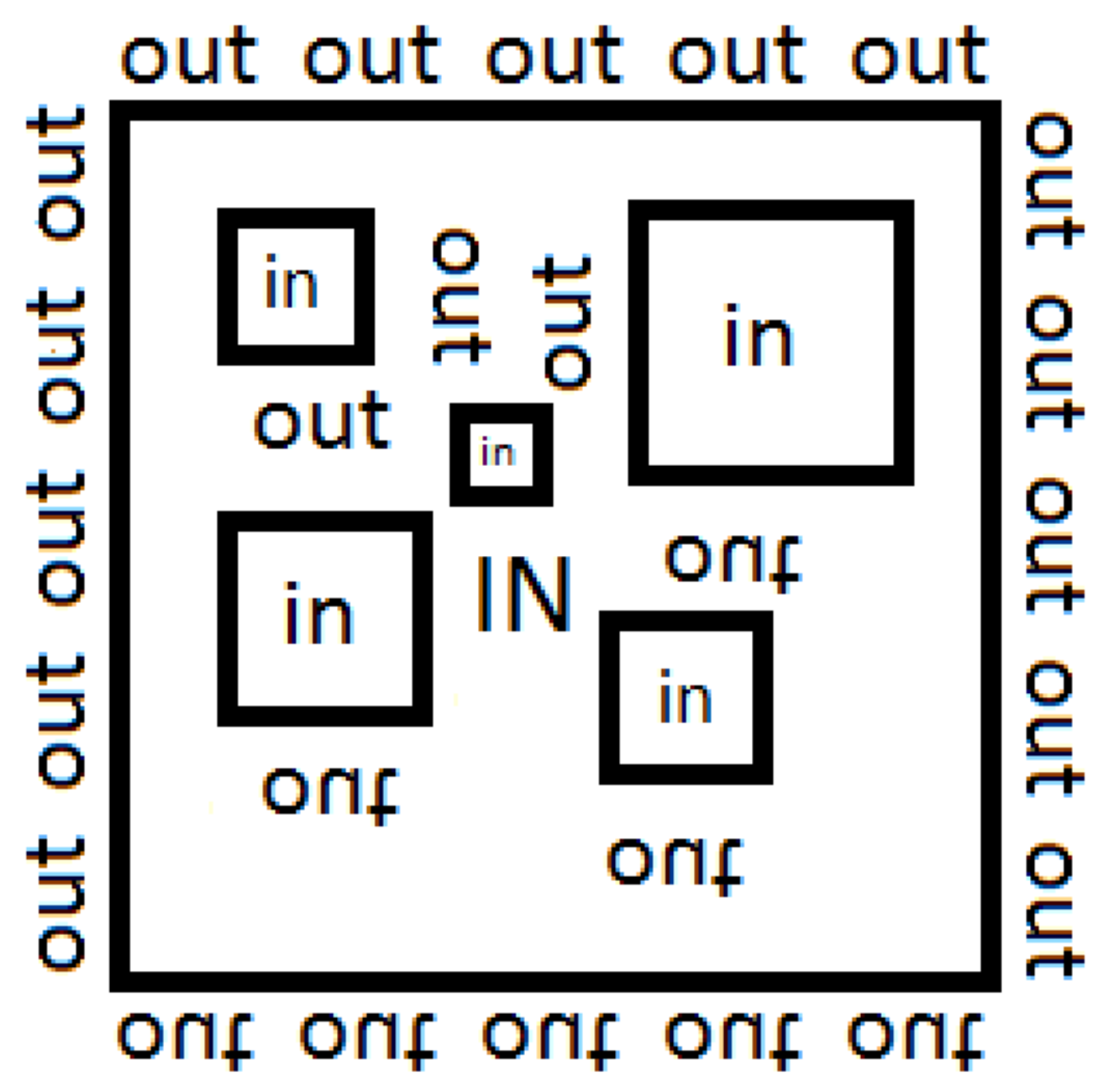


Affective perspectives taken placement

broader land s of many many many

multiples

tabled commons but different in number

that's okay

the differentiated metastasized leaves of bladed grains

inbetween the inbetween spaces

which is mostly full

of empty

empathied to a stationary position

whose pushed forward to new positions of positions

of posts of particles mand womand $(w o))(m((a)) n)) e d$

either or both and neither nor

for everyone

is

found in this translucent mold of me is the wiggle

of sub wiggles made up of various sub-sub wiggles

of the etc. cells

and both and snores at once with

neither/nor

yes is not

knotted together into the joints that make thing

sound

thoughts combed from fractal follicles of the hair

on our crotchs

that's always therer

this does this and is not that but could be with out of the the but with held

space that thresh holds

flesh flushed with joy

that it is seen as a flesh

savored as flesh

tenderized and genderized by choices not

projection screens

and rejection things

that's just the way 
we've been but

have to be could

have been the faulty

fallacy from the hair

on our crotchs which is there

and now some one else has

been here

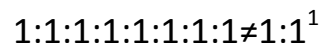

there is no 01101111011100000111000001101111011100110110100101110100

01100101

in the threshold

the only difference is difference and difference

is everything and everything is everything

which is lovely which is okay

which is okay which

is okay

${ }^{1}$ Read as "one to one to one to one..." 
I am in love with the day moth

though I hate it

The day moth that beats its wings

slow slack jawed and bears the weight

of its head to the window

that is nothing

to it

I envy the day moth

its unknown energy

since it does not see

the solid mass the separation

partition which it chooses to

not participate

in seeing

or hearing

or living

by the night and what

is proper of it should be in the outside

world rather than drawn to the false glow

of the warm love sun that is hanged with faulty wire energy

from my ceiling mantel top

unbeknownst to me the place space

that the day moth's aspiration

believes in is on the other side

of that glass partition

It doesn't exist

in our world

I love the day moth

for its head is hard but too hard to break but soft enough to not break

the glass it sees me

and it self

in the threshold of our proper location

and with wing beat power

and with hate for the window

that keeps me warm

during the space I occupy

in timely $\mathrm{C}$ sharp keys 
The day moth loves until it dies

on this side of the window

with Shakespeare's Sister

with me

holding our positionless pose

poised

to not participate

as the day moth does

And the window there

separate but existing

of all particles

like Shakespeare's Sister

like Anzaldúa

like Pierre

like Lorde

like Virginia

like Lemn

like a Galinsky

like Gunn Allen

like the day moth

like me

Hard to see the way out of the house in the house

of the sandcastle timeline

I love the day moth 
then, the quick pro's fell down the

oceanic stairs into the mental word

and I stepped into your space

and hate felt sighs of repetitive resentment |

met my hand

shake

with a middle finger

$I$ ate them and the heart burn fueled

my self righteous timeline

and I entered your heart

through the ventricles opening

to bear the antacid

and beer that cools the burnt

mess

and I found a singular stove dial that turned

me upwards of safe to each

and I couldn't help my hunger nerves

and devoured the entire article of capillaries

and felt the heart burn heart in my toenail cells

ringing the familiar bell beat tone

you are left in the epicenter

and I hate yourself

and I hold the chastised feeling in the back

of my throat until it fills my mouth nosed ear

bell beat rings the tone

and I eat the heart burn vomit

and I am sick

so I enter your brain waves through the right side

if found

left handed

to search for a silence to your

tone beat

to stop it

to stop it 


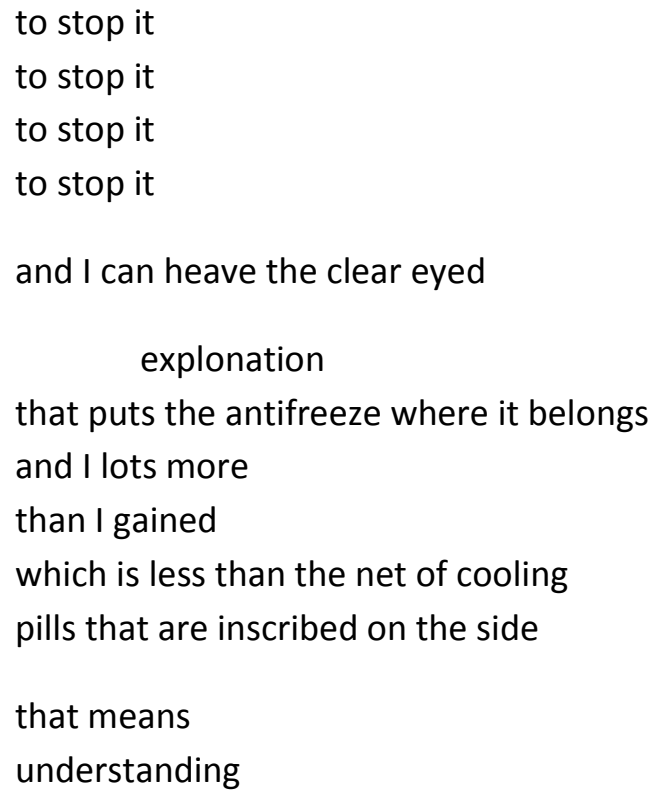


Otherness becomes empowering critical difference when it is not given, but recreated. Defined with the others' newly formed criteria - Trinh Minh-Ha 


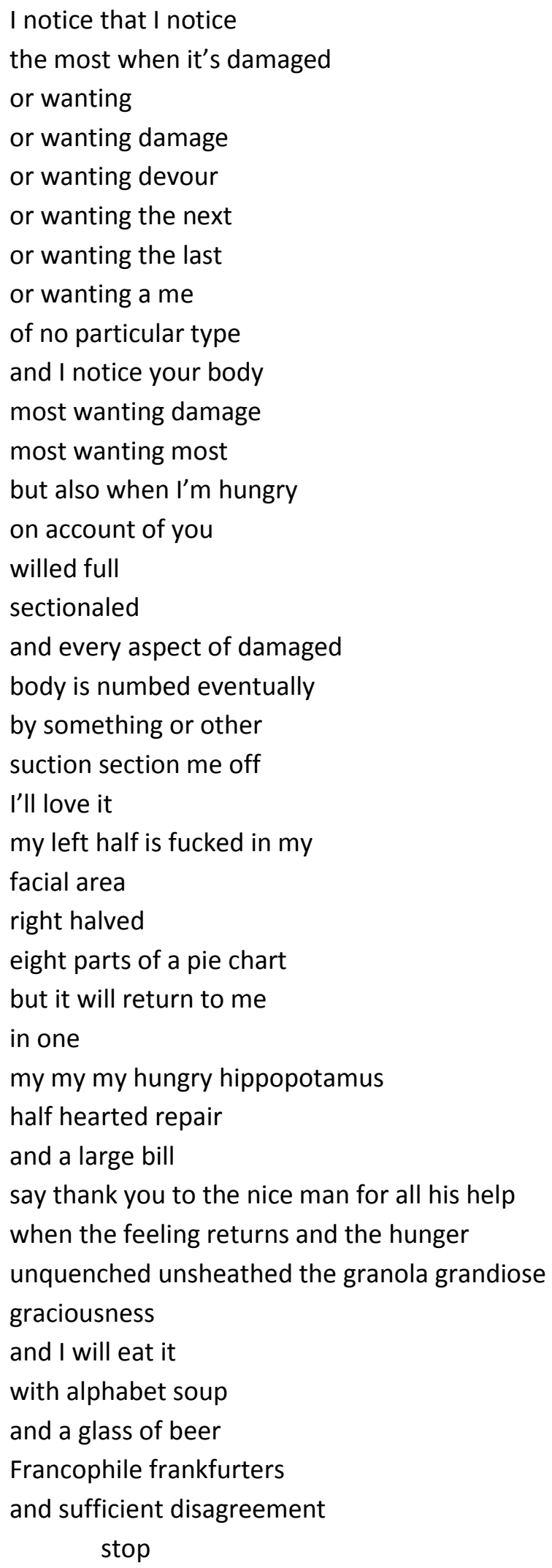


If you never knew us would you ever

would you ever love anymore

would you ever hate anymore

has superman yet killed Lex Luthor

or has everyone's embracement antithesized

love/hate

the rivalry of scholarly studies

and sutured spelling bee injuries

with laughter and recognition

What team is equal to you because my time is preciosity

and I would like to destroy you

if the wrong answer is my answer and your answer

is also wrong. defending the right to point

attacking the right to attack I

give yourself to something

other than yourself

and distrust the distraught one who can't see passing of the bullet for

the back is as worthwhile as inserting something profound in to a place not lost

Then the then monument to manimals can come crashing down into a collective bile of dust

that the people rub into their eyes

until they can see

friendship

and taste laughter

and learn to hear when they should love the others opposition

and achieve great

because the sound has never been so

as to be helped in helping

those I've never know to never fear anymore 
Oh---------on--------th-e---oth--er-------si--d--e---of -----t------he------l-i-n------e----------- $\rightarrow$ that body

Field of vision

the vastness expansive between

us

Un be knownst to us the closeness we will

be forced

to encounter counter

counted that something will end

someone must always be on the losing

side

Of the line

And my body is prepared

sacrifices

to the un known places

and blades upon faceless

bodies that become numbness

numbers

and words

worth a moments passing

That body

Past mine

and it won't ever happen again

strike

strike

strike

strike

stricken with anger dose

of adrenaline

it comes through the mouth holed open flood straight to the brain stem inject fear project calm the eye of the strong centered

and at peace

to act

when faced

that body

choice taken never there act is all

my body

downed 
up and forth back

downed

my body struck

to the turf

and bruised tissues

textured mandibles

and catastrophic tendons that body

blow after

beat shots

and bones

$$
\begin{aligned}
& \text { tear } \\
& \text { grit } \\
& \text { in } \\
& \text { tear }
\end{aligned}
$$

my body

that body

$$
\begin{gathered}
\text { and one } \\
\text { must always } \\
\text { lose } \\
\text { something }
\end{gathered}
$$

why is this the choice

$$
\begin{gathered}
\text { the thing } \\
\text { that decides } \\
\text { finality }
\end{gathered}
$$

my body

that body

$$
\begin{aligned}
& \text { destroy } \\
& \text { destruct } \\
& \text { contract } \\
& \text { expunge }
\end{aligned}
$$




$$
\begin{aligned}
& \text { expel } \\
& \text { erase }
\end{aligned}
$$

and its over

and my body

shakes

that body shakes

\author{
away \\ we have come \\ to a place \\ where we hope \\ to return \\ to decide \\ finality
}


A bunch of little cubbyholes stuffed respectively with intellect, race, sex, class, vocation, gender. Identity flows between, over, aspects of a person. Identity is a river, a process. Contained within the river is its identity, and it needs to flow, to change to stay a river. -Gloria Anzaldúa 


\begin{tabular}{|c|c|c|c|c|c|}
\hline self-other & self-self & other-self & self-other & other-other & same \\
\hline self-other & self-self & other-other & self-other & self-self & other-other \\
\hline self-other & self-self & different & self-other & other-self & same \\
\hline other-other & different & self-self & other-self & same & other-self \\
\hline different & other-self & self-other & same & self-other & different \\
\hline other-self & self-other & other-other & same & self-self & same \\
\hline other-self & different & self-other & self-self & different & self-self \\
\hline same & self-other & same & other-self & same & other-other \\
\hline same & other-self & different & other-self & different & other-other \\
\hline different & same & same & self-self & different & other-other \\
\hline different & self-self & other-self & self-self & other-other & self-other \\
\hline self-self & other-other & different & other-other & same & self-other \\
\hline different & other-self & self-other & other-self & self-self & different \\
\hline other-same-self & & different & self-other & same & different \\
\hline same & different & \multicolumn{2}{|c|}{ self-different-other } & same & different \\
\hline other-self & same & different & self-other & other-other & different \\
\hline self-self & other-other & self-other & other-self & self-other & self-self \\
\hline self-other & other-self & other-self & self-self & other-self & self-other \\
\hline self-self & other-other & self-other & other-other & other-other & other-other \\
\hline other-other & other-other & different & different & other-self & same \\
\hline
\end{tabular}


Tenuous: all I have in mine at best uh-huh but who wants to look upon it All I have in mind at most the bird flies at least the bird dies at best a rhyme but who wants to look upon it All I have in time repeated with dots and lines and shapes in the minds of you with 0111000001100101 011100100111001101110000011001010110001101110100011010010111011001100101 [who wants to look upon it] Elasticity stochasticity electricity in the mind is the taste of love but who wants to look upon it Took my don't see as/ see what see how see why percept except but who wants to look upon it Strange embers of stoma and fallen feathers further the myth of the antithesis but who wants to look upon it Strange casters of oh-no tenuousness less 
It will be December 12th. It will be Wednesday. It will be 10:40 PM. There will be two men. The two men will not know each other. They will not meet. They will not know the name of the other man. There will be two young men. They will not know the two men. They will not know the other two men's names. They will all four be in a city. The city will have been known for liberty. The city will be quiet. The city will be moving. The city will be quietly moving around the four men. I will be in a different city. I will be kicking a ball. I will not know the four men in that other city. I will not learn the names of the four men in the other city. They will not know that I will be kicking a ball. I will kick the ball with the intent of putting a hole in the wall with it. The four men will be in the city at the same time I will be striking the ball. The ball will be satisfied. The ball will be happy to serve its purpose. The ball will be dissatisfied. The ball will fail to do what I want. The four men will not know of the ball. The four men will be satisfied because they will not know the ball is dissatisfied. The four men will occupy a train. The train will be raised. The train that the four men occupy will not be the same as the raised train of the city I will be in. The trains will be relatives. The trains will be distant relatives. The trains will never meet. The four men will assume that the trains will never meet. One of the two men will be satisfied with being on the train. The other man and the two young men will be aware that the one man will be satisfied on the train. The man who will be satisfied on the train will be celebrating. While the man on the train will be celebrating I will be unaware that the man will be celebrating. The man will be unaware of my lack of awareness. The ball will be unaware. The ball will be blissed. The ball will be aware of bliss. The man on the train celebrating will feel the bliss of the ball. I will be unaware. The man will be unaware. The two young men will become too aware. The two young men will not be celebrating. The two young men will be antibrating. The man on the train who is celebrating will be aware. The other man will be aware. The ball will be aware. I will be unaware. I will kick the ball. The two young men will make an attempt to cease the celebrating of the man on the train celebrating. The talk will be trash. The talk will be unaware. The talk will be aware. The man on the train celebrating will respond to the two young men on the train. The talk will be trash. The other man on the train will be aware. The other man on the train will attempt to pick up the trash. The man on the train celebrating will ignore the other man on the train. The man on the train celebrating will tell the two young men that they need to watch their mouths. The man on the train celebrating will refer to young children and ladies on the train. The two young men will not ignore the man on the train celebrating. The ball will ignore all of them. I will ignore all of them. I will not ignore the ball. While I will not ignore the ball the two young men on the train will not think about the man on the train celebrating. The man on the train celebrating will not think of the other man on the train. The other man on the train will think of the other man on the train and the two young men. The ball will think about me. I will think about the ball. The two young men will not think about me or the ball. The two young men will get off the train. The man on the train celebrating will think of celebration. The man on the train celebrating will not think of celebration. The two young men will exit the train. The two young men will pause once they will have exited the train. There will be a hand gun. The hand gun will not be aware of me or the ball. The two men on the train will be aware of the handgun. The two men on the train will think of the bullet in the handgun. One of the young men will point the 
handgun into the train. The train will be stopped. People will be getting off the train. People off the train will look at the hand gun. People on the train will look at the hand gun. The hand gun will be focus. I will not look at the hand gun. I will have looked at the gun. One trigger will be pulled on the hand gun one time. The one of the two young men will pulled the trigger. The one of the two young men that will pull the trigger will not think about the men on the train. The one of the two young men who will pull the trigger will not think of the women and children and other men who will be on the train. I will not think about any of the women and children and other men who will be on the train as I will kick the ball. One bullet will travel out of the barrel of the hand gun and will be rotating. The bullet will be traveling faster than the eyes of the people on the train will be able to see. The bullet will navigate the white space. The bullet will be satisfied. The bullet will be happy to serve its purpose. The two young men will turn to walk away. The man on the train celebrating will be contacted by the bullet in the abdomen. The abdomen will be dissatisfied. The abdomen will be aware of the bullet. The abdomen will be unaware of the two young men that will be walking away with the hand gun. The bullet will navigate the abdomen. The bullet will pass the abdomen of the man on the train celebrating. The bullet will masticate the flesh and insides of the man on the train celebrating. The bullet will be aware of the stomach of the man on the train celebrating. The stomach will be dissatisfied. The contents of the stomach of the man on the train celebrating will spout into the inside of the man on the train celebrating. The bullet will be dissatisfied. The bullet will exit through the other side of the man on the train celebrating. The bullet will navigate the white space. The other man on the train will think about the bullet that will travel through the abdomen, stomach and back of the man on the train celebrating. I will not think of the entrance wound. I will not think of the exit wound. I will not think of the empty space created in the man on the train celebrating. The bullet will be satisfied. The bullet will travel at a speed faster than any eyes will be able to see. The bullet will settle through the flesh of the leg of the other man on the train. The bullet will be happy to serve its purpose. The train will begin to move. The people on the train will not move relative to the movement of the train. The people on the train will be moving. I will move relative to the train in the city that will be related to the train in the city I will kick the ball in. The two men on the train will remember the bullet. The two men on the train will not be satisfied. The two young men will continue to walk away. The hand gun will not be tired. I will not be tired. The lieutenant will say pulling a hand gun and firing will not make you a bigger man on the train it will make you an idiot. The lieutenant will talk as the young men walk away. The talk will not be trash. The trash will be satisfied. The talk will be dissatisfied. The lieutenant will look at the satisfied bullet. The lieutenant will be satisfied. The two young men will walk away. I will kick the ball with the intention of puncturing a hole. The ball will navigate the white space. 
Person with weapon last seen near Watterson Towers. Be alert, do NOT approach, and seek shelter

1. Factual Statements

and of sleep

turned lessons

about politics

and graveyards

2. The lovely student neighbor

walked direct the street

suspect to familiar

navigating to emptied spacelessness

the man with a gun turned out to be a man with a train ticket

that laughed in its dark made being the gun

was simplicity

3. My foot needs to go in the door

and my eyes to focus

but the darkness pines

and water paths

direct me to that dark hand

what's in that pocket

4. I have started to lose

at the click

but the things about transportation

not finality

5. No clue the promised they'd come to see him off pissed him off when I wouldn't be the at person

certain of danger

required of a towers place in face time

as the foreplay continued

6. But what of those without?

What of the man with the train ticket?

Has the Texas Eagle left?

AmITrack?

7. Being by herself made this even more terrifying and she hadn't seen

would she be on that train

to someone

who follows those/what was this? 
8. She

thought
it
was
upon
her
Too many bros for her taste
too fights
too many news
many different
too other

9. It turns out the police report read(s)

"after interviewing the student and suspect, we determined the student's

original statement was based on the fear he might have access to a weapon, but she later admitted having never seen a weapon

10. How who owns no weapon

11. The chest inhalation for who should be the at station

so you don't get locked in

to from which there is

nothing

to return from the fight or flight

creates these doesn't it

12. What's unclear is that it's unclear but clarity. Clarity. Clarity. Clarity. Clarity. Clarity. Clarity. Clarity. Clarity. Clarity. Clarity. Clarity. Clarity. Clarity. Clarity. Clarity. Clarity. Clarity. Clarity. Clarity. Clarity. Clarity. Clarity. Clarity. Clarity. Clarity. Clarity. Clarity. Clarity. Clarity. Clarity. Clarity. Clarity. Clarity. Clarity. Clarity. Clarity. Clarity. Clarity. Clarity. Clarity. Clarity. Clarity. Clarity. Clarity. Clarity. Clarity. Clarity. Clarity. Clarity. Clarity. Clarity. Clarity. Clarity. Clarity. Clarity. Clarity. Clarity. Clarity. Clarity. Clarity. Clarity. Clarity. Clarity. Clarity. Clarity. Clarity. Clarity. Clarity. Clarity. Clarity. Clarity. Clarity. Clarity. Clarity. Clarity. Clarity. Clarity. Clarity. Clarity. Clarity. Clarity. Clarity. Clarity. Clarity. Clarity. Clarity. Clarity. Clarity. Clarity. Clarity. Clarity. Clarity. Clarity. Clarity. Clarity. Clarity. Clarity. Clarity. Clarity. Clarity. Clarity. Clarity. Clarity. Clarity. Clarity. Clarity. Clarity. Clarity. Clarity. Clarity. Clarity. Clarity. Clarity. Clarity. Clarity. Clarity. Clarity. Clarity. Clarity. Clarity. Clarity. Clarity. Clarity. Clarity. Clarity. Clarity. Clarity. Clarity. Clarity. Clarity. Clarity. Clarity. Clarity. Clarity. Clarity. Clarity. Clarity. Clarity. Clarity. Clarity. Clarity. Clarity. Clarity. Clarity. Clarity. Clarity. Clarity. Clarity. Clarity. Clarity. Clarity. Clarity. Clarity. Clarity. Clarity. Clarity. Clarity. Clarity. Clarity. Clarity. Clarity. Clarity. Clarity. Clarity. Clarity. Clarity. Clarity. Clarity. Clarity. Clarity. Clarity. Clarity. Clarity. Clarity. Clarity. Clarity. Clarity. Clarity. Clarity. Clarity. Clarity. Clarity. Clarity. Clarity. Clarity. Clarity. Clarity. Clarity. Clarity. Clarity. Clarity. Clarity. 
Clarity. Clarity. Clarity. Clarity. Clarity. Clarity. Clarity. Clarity. Clarity. Clarity. Clarity. Clarity. Clarity. Clarity. Clarity. Clarity. Clarity. Clarity

is like reconciliation

Must we always polarize in the order to polemicize? Are we trapped in a politics of struggle where the representation of social antagonism and historical contradictions can take no other form than a binarism of theory vs. politics? Homi Bhabha 
The sign read

God Bless the Shooter

Language is not hate

inspired by language

My $h$ is a weapon

$m y h$ is a tool

that can

meant to maim depress-oppress

The other

uses

my h to kill me

with the I I use

the I

break the $\mathrm{h}$

see the

truth

in the I

God Bless the I!

Language does not inspire

hate

Hate abuses language

in a basement

Shackled

water boarded

advanced language

interrogation

Kill the language with my language

spread the hate

on the sign

with a butter knife 
There's a simple explanation

in this setting on the openness

of conversation that's lacking with out

lead and understanding

of all the differential minds

that came together contemplatingly necessities of exclusivities

$\begin{array}{ll}\text { that } & \text { though } \\ \text { time } & \text { I } \\ \text { I } & \text { am } \\ \text { saw } & \text { a } \\ \text { he } & \text { he } \\ \text { wasn't } & \text { and } \\ \text { like me } & \text { like me }\end{array}$

I turned around to contribute my wholeness

to the ownness of the larger part of the me

that lingers in my left pocket

emptied to fill us

but not them

them is a four letter word

used by us to describe them

expensive as it is to be

expansive with out them is how it is supposed to be

is what they say

and I've forgotten why I came to be and remember

that this could be them 
I am who I am, doing what I came to do, acting upon you like a drug or chisel, to remind you of your me-ness, as I discover you in myself. - Audre Lorde 


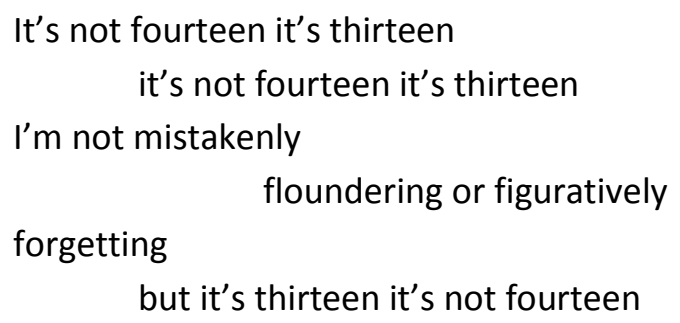




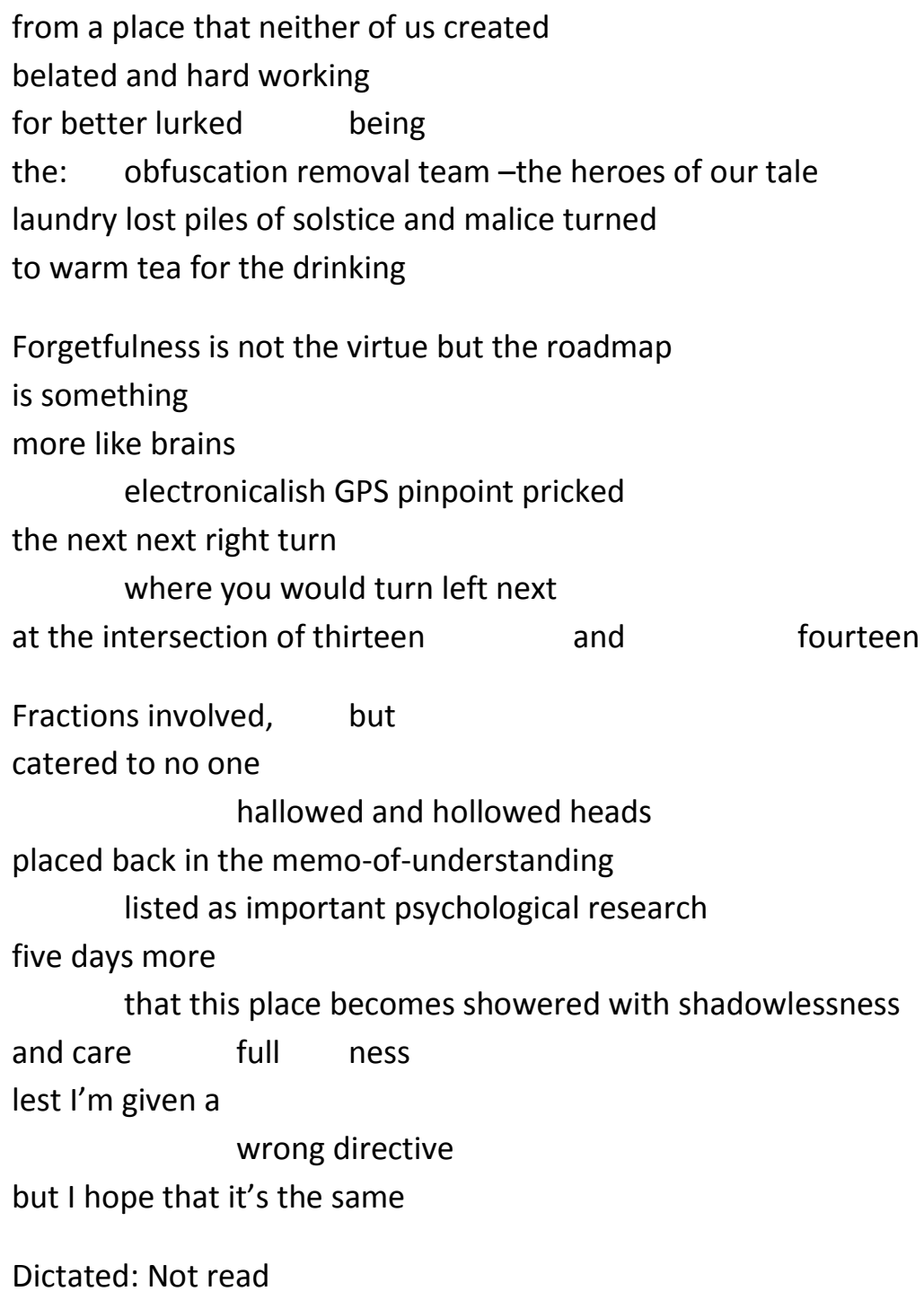


Using both your head and your heart

Success in

strategic conflict situations

necessitates

a clear

nuclear

perspective

on perspective suggestions and ability to mimic perspective

on perspective suggestions

and ability to mimic current, self, between retractions, considerable viewpoints, and mirrors

Key: flexibility

in cognitive biased games

,impasse and mixed motive interactions

thunk

$-E M P A T H Y-$

(in)pathetic strategic distributive outcomes

- $\quad$ an adverse

adversary bound to the self

healthy necessary priorities primarily allow assertive (dis)advantages

don't feel

-Negotiators-

Taking tendencies from tendonitised buyers at lower reservation price called familiarity

cost the parties sale price

dyadic dyads

parties, traits,

virility, validity vocalized opportunity

bought as binaries 
-Mixed Motives Move More-

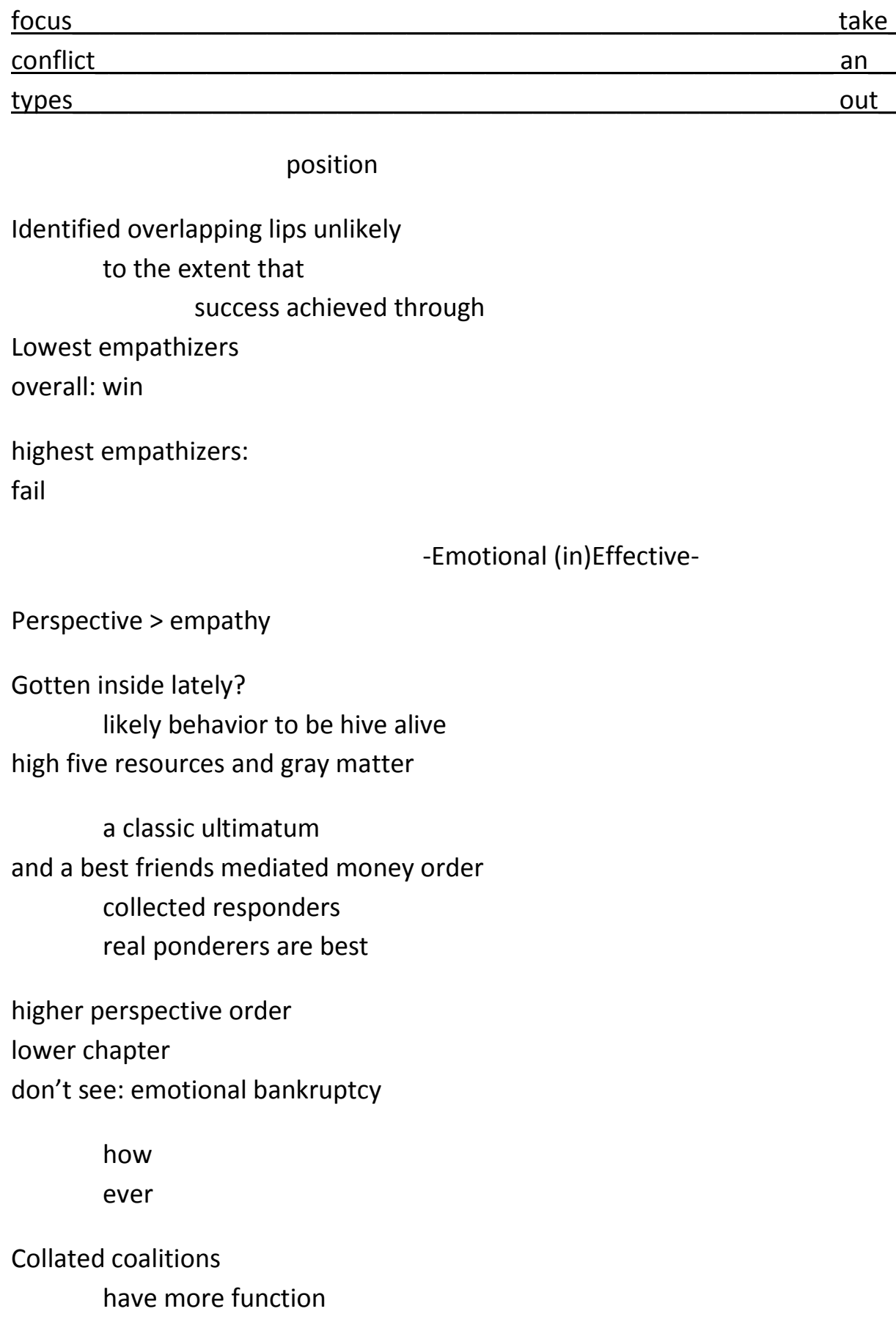




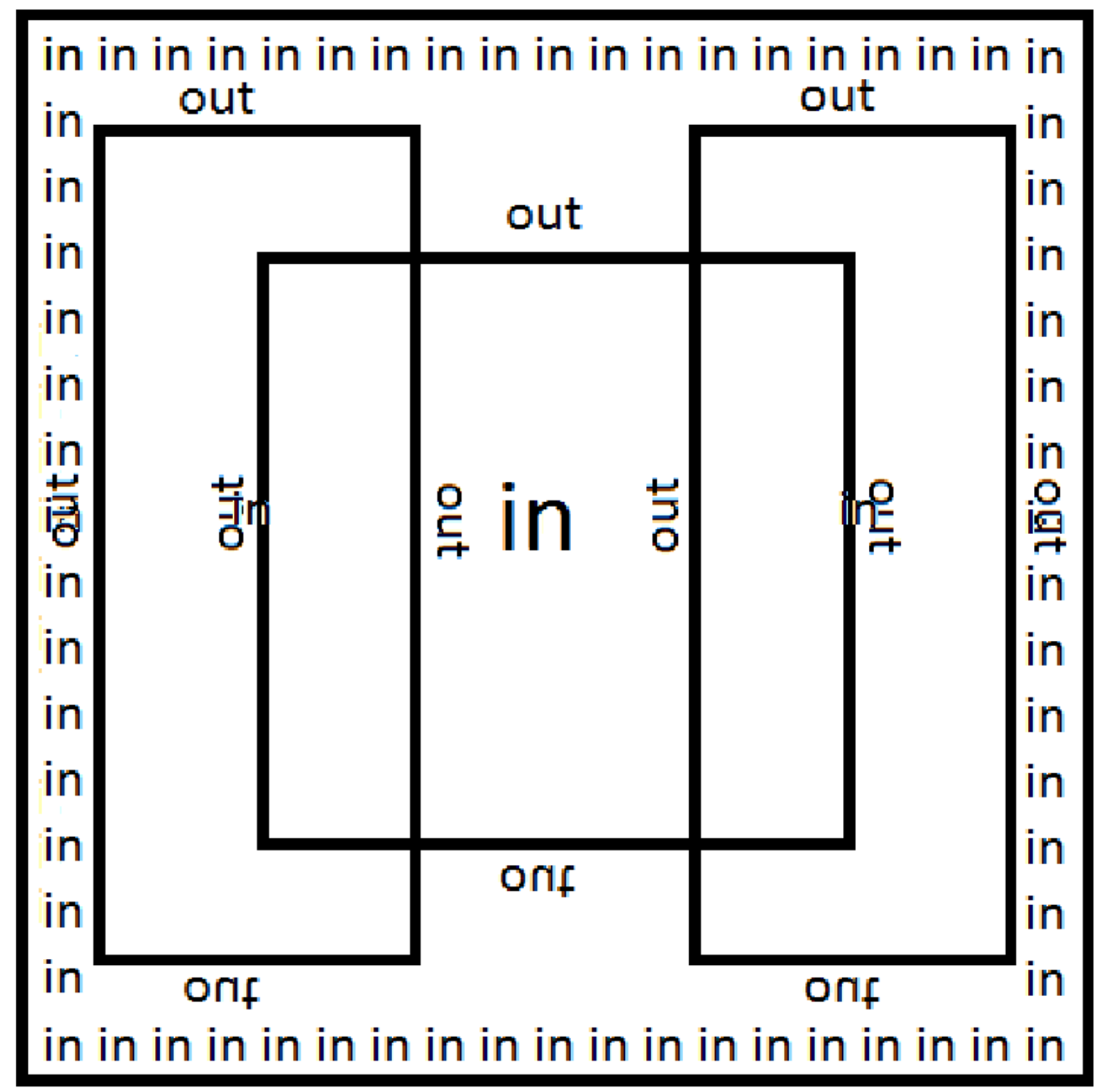


and that is more of what happened than anything important rather I would like to talk about how important that statement was in relation to things that actually don't happen when we make an effort and fail and feel like the blame falls on us, not us as in us or US (as in USA as in United States of America as in America) but us as in me as in I as in you as in he as in she as in individual as in one opposed to the reality and brevity of the situation which is to say, rather, it is us rather than you rather than me rather than I rather than he rather than she as in us as in you and I and he and she that is to say we as in us (but not as in US as in USA as in United States of America as in America; though it could be)and it should be in our systems to remember to forget to not remember that the individual is composed of a multitude of individuals at all levels that work together to fail and fall and get back up to fuck shit up and do what we have to to help that other individual comprised of individuals to be like the individuals we wish we all were at one point in time though it is through the act of actions and recognition that we see that you as in I as in me as in us can and cannot isolate a cell in our bodies being for consumption and compromise but can and will continue to forget to not 
More dissapproval that has one $s$ in the place of two

two hands that make contact to make ten which is often awkward

with two w that navigate that's not supposed to be there

ore there without an e that was supposed to be here rather than the there

what does you w mean

the table shifted

Down

this has nothing to do with the table shifting

Up

physics has everything to do with everything

I'm going to destroy much of this

with a d

which is really a key

Down

and I will refuse to be passive in my aggression

my symbolism of violence will not take place in two dimensions

Down

the tangibility of physicality when I fist strikes flesh in time is fitting of what I mean

Level

the language fist and middle finger are

Up

damned damaging

usurped slurped cylindrical position spaces

take

Down Up

the lovely

the

Down

ones who whose whoever that is please forgive

to cross the threshold

Down

I had to utilize the restroom

that utilitarian momentous side of my face that rectifies the end of the story with a word

Down

BAM

BAM

POW

a caricature of a milder time

Up

this is getting cross condensationed

Habbitual habits with one of two $b$ 
that will cat

and stay

the paper only bleeds internally

some of this must be worthwhile

something must be worthwhile

can the sense of the words place you? 
Boston's a place I have never been

Stunned in silence from the noise made by the crowd cheering the feet movement to the ground relative to the rotation of everyone else

Silent in some hot-wired contraption that wasn't in the plan but it still here so we have to deal with it and whatever it's called

Hate? Hatred? Forgotten misconceptions of a mind less?

Stunned by the one that feel from the first that blast came in second placed a few blocks away to cover as much as possible

A failure of words. A failure of perspective. A failure of understanding. A failure as understatement.

A personal best of death

We cannot run from these things that come at us like violence

Bloody miles pump hearts and shirts as tourniquets are finish lines and we should be proud

But we cannot stop running

Stunned in silence to act in actions and keep moving feet on streets in celebration of fucking life And we should be proud

If you can't run that far start slowly but understand that there are some that will run faster. The elites weren't Americans I suppose and we should be proud

Target the ones not quite fast but still finish

Those guilty spectators guilty of spectating and cheering for something greater than the sum of us all and it was something someone supposedly related to them did that is unknown to the known

But it's always more complicated than a bomb in a pressure cooker isn't it the easy

And we should be proud

The feet are the hard way. The words are the hard way.

And we should be proud of what came back across the finish line 


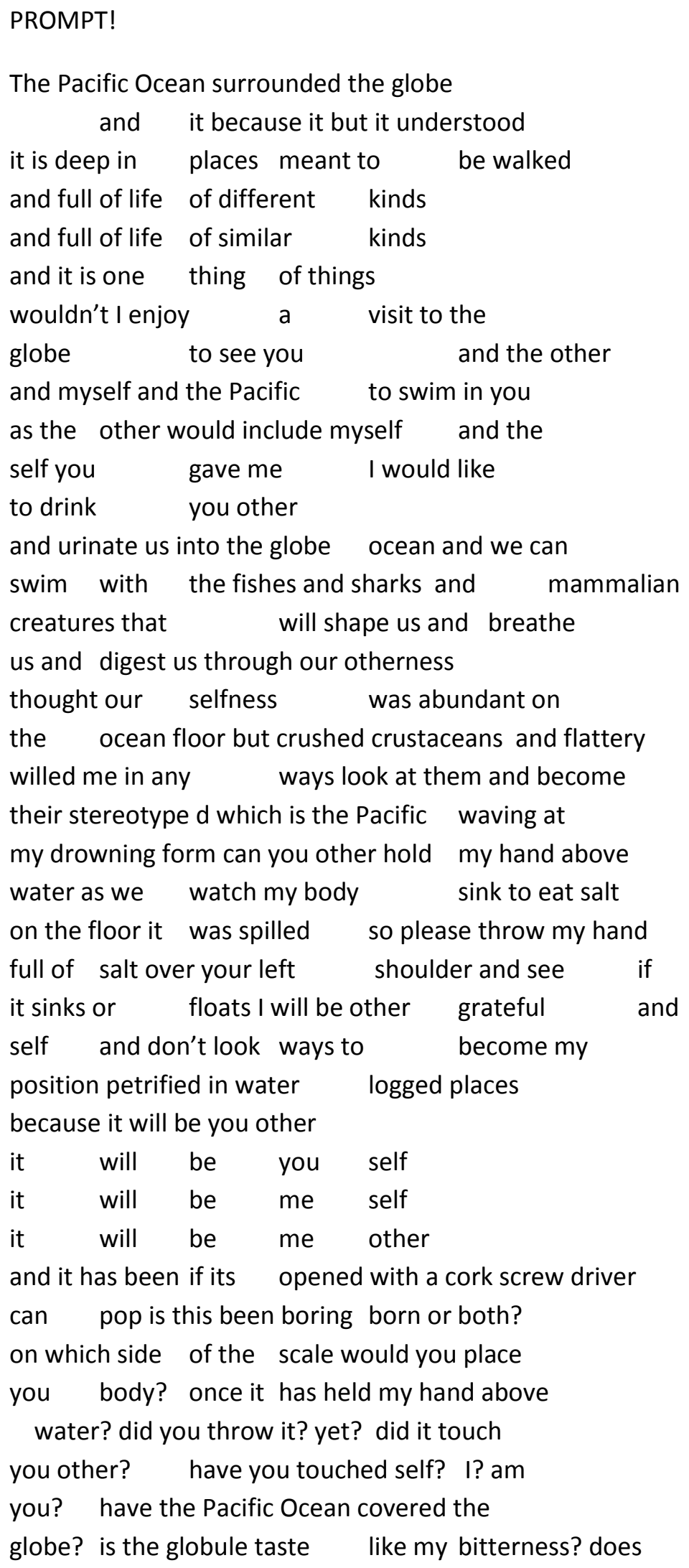




\begin{tabular}{|c|c|c|}
\hline \multicolumn{2}{|c|}{ smell as } & rancid as the lonely? \\
\hline being disconnected & from & tap one to \\
\hline seven and know & & how am I still? \\
\hline if you had taken & my pl & ace position you are more \\
\hline likely to understand & and $\mathrm{I}$ & don't \\
\hline
\end{tabular}


We have been organizing on the basis of identity, around immutable attributes of gender, race and class for a long time, and it doesn't seem to have worked. - June Jordan 
1. two sided things come around more than one

they boom

around in the light spaces

day and night are not binary

they are constantly ready but not

wanting to fight and what happens

when the corners fall off and move

toward the outside like slow continental drift

of bodies?

who's there to coral the sheep

and do a head count

to keep the maximum capital?

the chief philosophical officer.

2. I see the drip spots in between mouths

and faces

faces focus on faces focus on faces focus on faces

we smiled. we stepped into the mouth on faces

and did not chew.

I always see eyes. the eyes always see me looking

at faces and bodies and movement and blurs.

I see eyes see. and what is on the outside

does something. rounded and flat.

3. The smallest parts make up the largest particles

and the dots are larger dots in the picture. $I$ is made

up of lines and ink and concepts and skin and finger nails

and blistered bones and others.

Place a hat on top and I becomes something completely different.

When I becomes me and me becomes self and self becomes other.

Heavy dotted at the bottom for balance

but certainly isn't considerable

4. The face says the words obey. The face isn't a face so

I'm not sure what to focus on.

The obey commands. But the obey is vague

so I don't see the movement. The fit is

faulty so stop trying to box it. The blue one

may work best

but nothing can be better.

Symmetry, darkness, chin marks, light, the feeling

this thing should feel and then be

digested.

Symmetry, darkness, chin marks, light 
5. The resurface of the world resulted in repercussions convenience went to those who stayed and happiness comes to all who try to travel though the center because the floors are lava and I died six times already today so. Please say that you can at least understate my points of view hash tag this used to be a pound sign/mean number/a game but it's not anymore and can too 
I.

In the car

in the parking lot

of the coroner's

office

some light

reading

I look up every few seconds

for her

I hear the muffled mumblings of a woman

through the phone

loved one lost

my belly full

of good things

come to those who wait

her work is so important

painful

the lost who gives

the found gains

we all gain

little

what is my part in this play?

sit

wait

for time

for moments

let's face it

who appreciates as much

as should

as could

as will

gone went

gone lost

the cul-de-sac is just as dangerous

the dog barks a soft tune

car stereo

in the parking lot

of the coroner's office 
II.

In the car

in the parking lot

of the coroner's

office

I wait for her to emerge

to walk

out

to leave this place

the distant

creeks a door open

young woman: slink out

$\begin{array}{lll}\text { head } & \text { tears } & \text { wipe } \\ \text { held } & \text { slow } & \text { slow } \\ \text { high } & \text { flow } & \text { nose }\end{array}$

I can't quite see her

but I hear her tears

and I feel her crying

the purity of loss found sadness

she walks

sits in her car

behind me

I can feel her staccato

speech through the open window

I want to walk over

to her

put my arm around

her

stranger

but I understand

I am here

you are not alone

you are not alone

you are not alone

you are not alone 


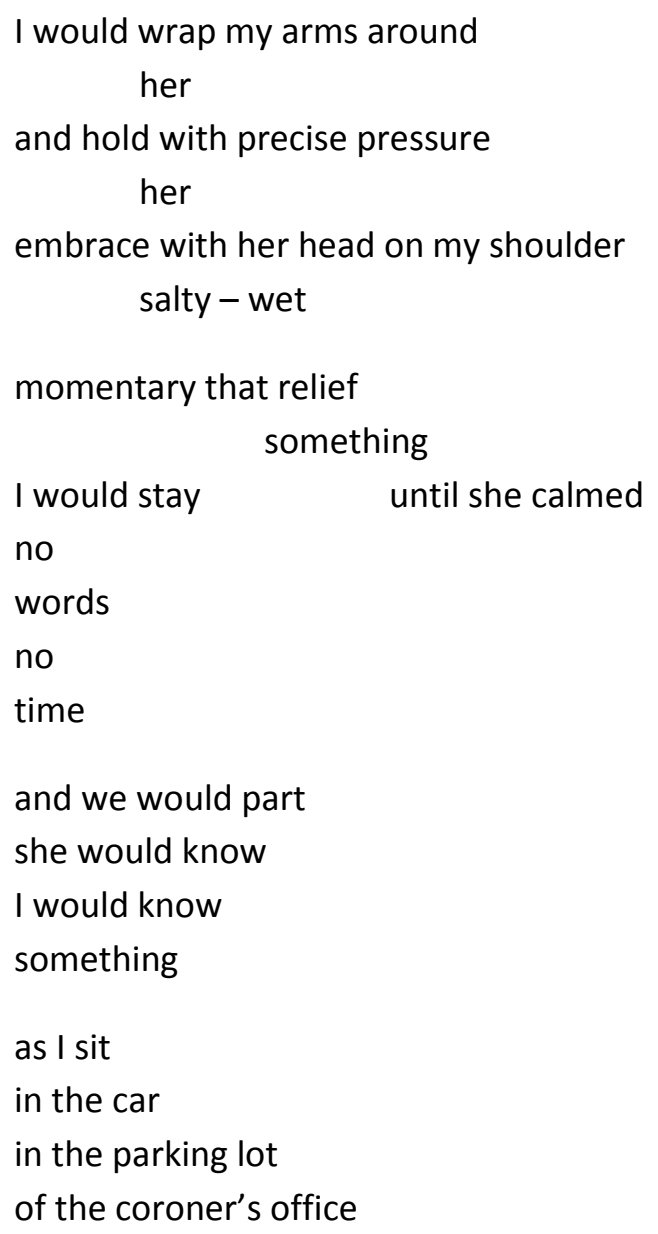


Marvin Norwood [age 31] on the phone to his mother after being arrested

I was involved, I was. To a certain extent I was involved I was to a certain extent I was involved I was involved I was to a certain extent I was involved I was to a certain extent I was to a certain extent I was I was involved I was to a certain extent I was involved I was to a certain extent I was involved to a certain extent I was to a certain extent I was involve di was I was I was to a certain extent I was involved to a certain extent I was I was involved I was to a certain extent I was I was involved I was to a certain extent I was involved I was to a certain extent I was involved to a certain extent I was involved I was involved, I was. To a certain extent I was involved. 
Not quite the Same, not quite the Other, she stands in that undetermined threshold place where she constantly drifts in and out. - Trinh Minh-Ha 
The Raven

It's simple, you know, God has never made a mistake. That's just who He is, you see? And if our system - this is the sad thing about our system - if our system took the time to really investigate what happened 13 years ago, maybe they would have got to the bottom-line truth. - Ray Lewis (2013)

Once upon a midnight dreary the parking lot rang light with actions

at the Cobalt Lounge

Come to see the celebration of all Americas

mastication of chicken wings and beer and pigskin

Partly parked fellows

meet in the open

spaces - here/ there

heavy faces and the power of language

compels, repels, propels, and (re)compels

the notion of all commotion to take to the streets with with

who the fuck do you think you are

quoted from the scene

Quote the Raven: yes, something like that

A Ray

Ray Ray back by the limo Ray back Ray as the observer

Ray Ray who was standing

Ray there perched upon

Ray

something like that

They came back towards the limo

they: unwanted, they: unasked, they: unsettled

they: who the fuck they knew they were they

toward Ray toward them back at them

they:Ray:them

and all asunder and fire, thunder

the celebratory weaponized formed in the skull

MOET thud

unbroken but something is 
here this parked lot of men

popped in the cork and the bubbles flowin'

and what happened

a symphony of liquor fists

amongst others

and the same phony language

that birthed

or truth

all known

Quote the Raven:

Escape! Quickly to the bullets fire

"we kicked they ass"

and full perspired beating hearts bleed faster fore

and the pavement parked men stayed

and were

nevermore

Quote the Raven: just keep your mouth shut and don't say nothing

nothing.nothing.nothing.nothing.nothing.nothing.nothing.nothing.

nothing.nothing.nothing.nothing.nothing.nothing.nothing.nothing.

noting nothing

Is it OK if I call you Ray?

call you call you

open up

the entrenched middle of the field

has

moved leveled from the blacktop

assessed a charge. Charged. Batteried

not in the slight of hand

Not found: fingerprints white suit minks minks minks minks

found: Ray there Ray

I wasn't there

An obstruct obvious of the things he had seen hadn't

he hadn't had he hadn't 
been under the oak

with the sweet

sweating with the knife soaked

rest

rested

arresting indicated indictment also them

Howhard Howhard

to see the stars be humanized shot from the canonized placement

meant it but couldn't

Howhard Howhard put pull in the place

and realization follows suit from the failure

of language that sits atop

the already failed language

To Settle:

1. To place as to stay

2. a: to establish in residence

b: to furnish with inhabitants

3. a: to cause to pack down

b: to clarify by causing dregs or impurities to sink

4. to make quiet or orderly

5. a: to fix or resolve conclusively <settle the question>

b: to establish or secure permanently

c: to conclude (a law suit) by agreement between parties usually out of court

$\mathrm{d}$ : to close (as an account) by payment often of less than is due

6. to arrange in desired position

7. to make or arrange for final disposition of <settled his affairs>

Dealt the cardstock filed and agreed on all accounts

all known: Obstruction

justice

just as ice melts in the hearts slain

and tested testimony. Distinctly remembered

it was the bleak January

new year just a moments ago

Howhard Howhard

mealy-mouthed answers 
Quote the Raven: yes,champagne bottle,I saw him hit over the head?,once he hit over the head, in all honesty, all hell broke loose from that point,it was - from that point it was chaos. When he hit him in the head, them two just went into a dramatic fashion of fighting,no, no,correct,yes,correct,correct,correct,correct,correct,correct, right,fourfour,yes, probably not, it could have been,yes,correct,yes,correct,right,all the time, right, not at all,right,correct,correct,right, are you helping him because he is your friend? No,yes,yes, definitely,correct,correct,correct,right,right,correct,right,correct,correct,correct,correct,correct, $r$ ight,correct,correct,correct,correct,right,they came back towards the limo,me and Joseph, right, right,yes, something like that,correct,correct, right, right, right, right, that's what tripping means, yes, right,correct,correct,correct,correct,correct,correct, I mean...,you know, it was like, we were getting ready to go and as they were approaching - I mean, it was almost an equal or mutual thing, I don't know. Well, yes, we didn't leave because they came back, I guess, I don' $\mathrm{t}$ know, right, they were coming back,no, well yes, correct,right, right,right, right,correct,right, right,correct, right, no, no, no, right, no, right, I was probably a little closer, yes, right,yes, right, no, right, no, no, no,yes, yes, yes,correct,no,yes, I mean, when they hit you, yes,yes, no,well, as soon as A.J. walked up there and approached them, he hit him in the head with the bottle. Just came across him,yes, right,right,right,yes,yes, yes, yes, I guess, right,yes,correct,correct,yes, I've seen it,correct,right, right,yes, right. I saw him - he was fighting at that time. I just saw the hands being thrown at him,right,yes, I was looking at him,no,right, they was both punching,no,yes, no,right,yes,yes, I told them I didn't feel right, yes, I just told them I didn't feel right,right,yes, exactly, right, no, no,yes,yes,yes,yes,yes,yes,yes, he could have been,yes,yes, correct,well, I just - like I said I characterize what I saw, it could have been, right, right,correct, no, no, no, right,all right. He's saying...,right, I grab him, right, right, no, right, no, no,yes, that's what they called me,yes,yes, no, no, no, right,smooth,smooth, right,correct,correct,correct,right, I mean, you don't have to look in two places at once if they're right there in the same area, no, not the while time,oh, OK, right,correct,correct, right,right, right,yes, well, what I said I saw is what I saw the two guys grab Joseph. I don't remember what Jeff Gwynn said,that's what they were doing to Joseph,right,correct, at that time,right,correct,correct, right,correct,correct,correct,yes,correct,correct,correct,correct,correc t,correct,correct,right, right, no, right,correct,correct, no,no. Yes, I don't remember him, right, as soon as we started pulling off, well, we pulled around the car - whichever car was that on the curb. I'm not sure,no, we couldn't go straight, we had to pull around,right,correct,correct,correct,correct,correct,correct,yes, right,correct,correct,yes, at that - yes, at that time,no,right - more mad than anyting,correct,no, right,right,I don't know about clean up. I just know everybody went up there,yes,no. I didn't see him,yes,yes, right,correct,right, right,yes, high school, we grew up together, all my life, right,right,correct, right,correct,correct,yes,yes,yes, right,correct, right, right,correct,correct, rig ht,correct,yes. Everybody comes back,everbody,yes,yes,yes, right,yes,yes, by the girls who sit on the couch,yes, exactly, right, right, right, right, right,correct, right,correct, broke, right, right. I had no idea,right,correct, who?,correct,yes. I wanted to know what happened, what went on 
really,right,right, he said it to me,I mean, I just kept talking from that point in time about - I sat down and asked him, did I believe him or not at that time?,I just went...,no,right,correct,no, no, no, no, no, no,no, no, no,yes, no, no,correct, ,right, no, nothing, no, no, I knew what she had on, exactly, right, correct,right,no. They had basically the same demeanor that Joseph and Kwame had. They were just sitting there just blurting off at the mouth really,no. no, no, no,no,exactly,because he was is won in the frantic mood that I had to - when I walked up there, he was the one with the most gestures, and so that's why I grabbed him and pulled him back to the limo,no, I grabbed him and I walked off,tripping - I mean you can use it in a lot of different terminologies but the way that Joseph said it when he said "You ready get in the car because these cats tripping?" When he said that, that means they fitting to come back to, you know, start something, or you know, just trip,exactly,yes,like I said, it can be used in so many contexts, if you're sitting on the inside, if you're sitting on the inside, you should be able to see out. You just can't really see in, not really,yes, right, no, not that I can recall,exactly, right, right, where they...,right, right, he went to help Oakley,no,no,exactly,yes,no,l assumed - somebody else said "aid." I said he was going to help Oakley, that's what I said,yes, when the fighting...,yes, to leave, whoever wasn't in the limo was going to be left,because I was the same one trying to stop the fight,all I said was, I'm out of here,everybody,me?,no,yes, I don't think I said nothing really at that time. I think when the limo was pulling off that's when everybody started getting down because of the gunshot,no. The only instructions I gave was - it wasn't instructions, it was just out of frustration, me saying that, you know, everybody is tripping, you know what I'm saying, everybody just shut the fuck up and just - because you're tripping, that's what I said. I didn't give instructions, that wasn't directed to say, defending?,no,no,OK, OK, right, right,yes, sometimes,could be,no,mad?,yes, the whole thing, what happened before - yes, basically, correct,I'm really not sure what...,yes, after he started fighting back?, right,I didn't - he was still fighting, after the fight was over, he ran back to the limo,like around the tree down further down by the sidewalk. Once he regained footing, is that what you're talking about?,down by the - they were still fighting down by the fire hydrant, where the big crowd was,yes, where the crowd was, where I showed you earlier, there was a crowd of people fighting down there. That's where he ended up at, because that's where he was running back from after, it was over. Yes, it was breaking up,yes,only when they started fighting from the first beginning,well, both of them were - they were just fighting really,yes, I

guess,correct,no,25?,ok,yes, yes,yes,no,yes,correct,I wasn't trying to say he forced me to give me anything. I was just saying that the way they asked me the question about how was the investigation or my statement was taken down, and I explained to them how it was taken down, I would use threaten before I use trick, well, that's the reason why I think I didn't really tried to understand why I was making the statement. It didn't really matter at the time about the statement. I was just trying to give them whatever they wanted to get them out of my face at that time,I tried to tell them anything they wanted to get them out of my face, I can tell you why I lied - I wouldn't have lied. So I can't say that,yes, right, no, no, no, no, no, no, right, right, exactly, right, right, no, right, yes 
Not tripped up at all in this others place faced

tripping as in - my career is over because you guys tripping

and dealt through deliberation

his focus on answers

TRUTH

Quote the Raven: something like that

So no seen stabs at the end

of the scene the audience left wanting

only blood in the limo

but that's not enough to be rated $R$

barely PG barely amongst the lively two left

out of that room except DNA but that's not enough

and deliberate and deliberate and deliver it

and the not weighs more heavily than the guilty

Wo wo when who had the purple

they:Ray:them

Not them not them not them not them

they no

no more

nevermore

through doors

Quote the Raven: but the saddest thing ever is a man looked me in my face and told me "we know you didn't do this, but you're going down for it anyway!" But if I had to go through all of that over again...I wouldn't change a thing

Success in the shape of a cereal bowl forgetting

spooned full of sugared healthy helping of winning

Defensive Player of the Year (2000/2003)

Super Bowl XXXV MVP

Thirteen time Pro Bowler

Seven time AP First Team All-Pro

Three time AP Second Team All-Pro

Two time All American

Lead NFL in tackles (1997/1999/2001/2003/2004)

2,061 Career Tackles

19 Career forced fumbles 
117 Career passes defended

102.5 Career stuffs for a loss

41.5 Career sacks

20 Career fumble recoveries

31 Career interceptions for 503 yards

1 Career safety

3 Career touchdowns

17 Seasons

What help

but those Lolled and Baked and

nevermore family, father, son, nephew

left there on the parking space the limo left with

DNA

Quote the Raven: those families that were affected will never know the truth. And that's sad.

But the truth is we do not know what the herring feels

and to understand the complexity of charity

you would have to been there

No no not not no

two bodies missing

Ever never not no no

Nevermore

Quote the Raven: If you really knew - if you really knew the way God works, He don't use people who commits anything like that for His glory. No way. It's the total opposite 


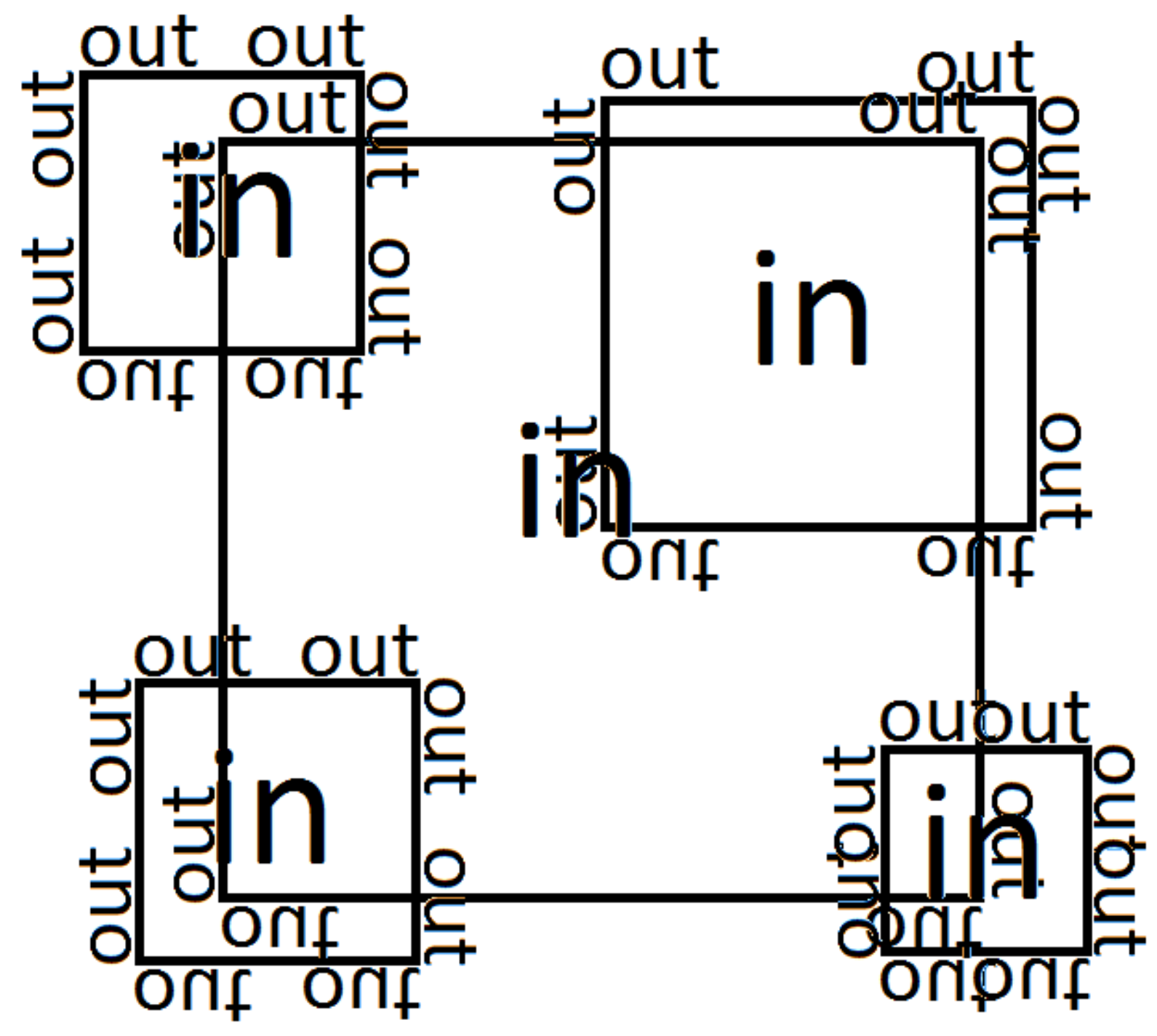


Being women together was not enough. We were different. Being gay-girls together was not enough. We were different. Being Black together was not enough. We were different. Being Black women together was not enough. We were different. Being Black dykes together was not enough. We were different. - Audre Lorde 


\section{REFERENCES}

Adut, Ari. On Scandal: Moral Disturbances in Society, Politics, and Art. Cambridge: Cambridge UP, 2008.

Archambeau, Robert. "Charmless and Interesting: What Conceptual Poetry Lacks and What It's Got." Harriet The Blog RSS. The Poetry Foundation, 02 Aug. 2013. 10 Nov. 2013.

Bedient, Calvin. "Against Conceptualism: Defending Poetry of Affect." Poetry. Boston Review, 24 July 2013. 10 Nov. 2013.

Bernard, Stephen. "Cohesion from Conflict: Does Intergroup Conflict Motivate Intragroup Norm Enforcement and Support for Centralized Leadership?" Social Psychology Quarterly 75.2 (2012): 107-30.

Berryman, Ted. "Kenneth Goldsmith Is a Hoax, or Fifteen Conceptual Poetry Projects Better Than Printing the Internet ." Internet Presence. N.p., 15 Oct. 2013. 10 Nov. 2013.

Bourdieu, Pierre. The Field of Cultural Production. New York: Columbia UP, 1993.

Brady, Thomas. "Kenneth Goldsmith Is Not a Conceptualist!" Scarriet. N.p., 30 Aug. 2013. 10 Nov. 2013.

Danchev, Alex. 100 Artists' Manifestos. London: Penguin, 2011.

DiDonato, Theresa, Johannes Ullrich, and Joachim Krueger. "Social Perception as Induction and Inference: An Integrative Model of Intergroup Differentiation, Ingroup Favoritism, and Differential Accuracy." Journal of Personality and Social Psychology 100.1 (2011): 66-83.

Fisher, Shell. "Can Flarf Ever Be Taken Seriously?" Poets \& Writers. Poets \& Writers, 01 July 2009. 28 Nov. 2012.

Galinsky, Adam D., Debra Gilin, and William W. Maddux. "Using Both Your Head and Your Heart: The Role of Perspective Taking and Empathy in Resolving Social Conflict." The Psychology of Social Conflict and Aggression (2011): 103-18.

Goldsmith, Kenneth. "Flarf Is Dionysus. Conceptual Writing Is Apollo: An Introduction to the 21st Century's Most Controversial Poetry Movements." The Poetry Foundation, 01 July 2009. 1 Dec. 2012.

Goldsmith, Kenneth. "Introduction to Flarf vs. Conceptual Writing, Whitney Museum." Introduction to Flarf vs. Conceptual Writing, Whitney Museum. Electronic Poetry Center, 17 Apr. 2009. 2 Dec. 2012. 
Goldsmith, Kenneth. "Paragraphs on Conceptual Writing." Electronic Poetry Center, 10 Nov. 2013.

Goldsmith, Kenneth. "Sentences on Conceptual Writing." UBU Web, 01 Oct. 2005. 01 Dec. 2012.

Goldsmith, Kenneth. "Uncreativity as Creative Practice" Kenneth Goldsmith. Electronic Poetry Center, 10 Nov. 2000. 02 Dec. 2012.

Gould, Henry. "Note Contra Conceptualism." HG Poetics. Blogger, 26 July 2013. 10 Nov. 2013.

Hejinian, Lyn. "Some Notes Toward a Poetics." A Best of Fence: The First Nine Years 1 (2009): 108-18.

Keating, AnaLouise. Women Reading Women Writing: Self-invention in Paula Gunn Allen, Gloria Anzaldúa, and Audre Lorde. Philadelphia, PA: Temple UP, 1996.

King, Amy. "Beauty And The Beastly Po-Biz." The Rumpus, 15 July 2013. 10 Nov. 2013.

Mead, Nicole, and Jon Maner. "When Me versus You Becomes Us versus Them: How Intergroup Competition Shapes Ingroup Psychology." Social and Personality Psychology Compass 6.8 (2012): 566-74.

Naik, Gautam. "Search for a New Poetics Yields This: 'Kitty Goes Postal/Wants Pizza': GoogleInspired Verse Gains Respect; Shakespeare Meets the Anagram Generator." The Wall Street Journal. The Wall Street Journal, 25 May 2010. 01 Dec. 2012.

Nowak, Mark. "Conceptual Writing [verb, Repeat] and Silence." Harriet The Blog RSS. The Poetry Foundation, 29 Apr. 2010. 10 Nov. 2013.

Robinson, Douglas. "Shklovsky's Modernist Poetics." Estrangement and the Somatics of Literature: Tolstoy, Shklovsky, Brecht. Baltimore: Johns Hopkins UP, 2008. 79-131.

Sawyer, R. Keith. Group Genius: The Creative Power of Collaboration. New York: Basic, 2007.

Tarrant, Mark, Raff Calitri, and Dale Weston. "Social Identification Structures the Effects of Perspective Taking." Psychological Science 23.9 (2012): 973-78.

"UbuWeb Vu: Kenneth Goldsmith." Interview by John Jourden. UbuWeb Vu: Kenneth Goldsmith. Archinect, 28 Apr. 2008. 01 Feb. 2013.

<http://archinect.com/features/article/59857/ubuweb-vu-kenneth-goldsmith>. 


\section{NOTES}

Perspective Taking - Page 22

This is a word track taken from Perspective-Takers Behave More Stereotypically which is a study by Adam Galinsky, Gillian Ku and Cynthia Wang. The word track is intended to prime the participants with perspective taking rather than empathy.

The Raven - Pages 66-72

Quote the Raven...:

It's simple, you know, God has never made a mistake...

From a 2013 interview aired on CBS with former teammate Shannon Sharpe before the Super Bowl. The question Sharpe asked Lewis was "What would you like to say to the families(of the victims)?" (profootballtalk.nbcsports.com)

Yes, something like that/yes, champagne bottle...

Quotes come from a rush transcript of Ray Lewis's testimony from the trial (transcripts.cnn.com)

Just keep your mouth shut...

What Lewis told the members of his party in the limousine as they left the scene of the fight (policymic.com)

But the saddest thing ever...

Quote is a combination of statements from Ray Lewis the same Shannon Sharpe interview from 2013 and statements made when asked about his feelings about the incident.

(profootballtalk.nbcsports.com/sbnation.com)

Those families that were affected...

Quote from Lewis from an interview after the incident

(sports.yahoo.com) 
If you really knew...

Quote from the same interview with Sharpe.

Career stats come from Wikipedia.com

"To Settle" definitions from Merriam-webster.com

On January 31, 2000 Jacinth Baker and Richard Lollar were stabbed to death outside of an Atlanta nightclub (Cobalt Lounge). Two men, Joseph Sweeting and Reginald Oakley, were suspected of stabbing Baker and Lollar. Sweeting and Oakley had left the nightclub with Lewis and his friends. There is no evidence that Lewis was culpable in the actual murders...But Lewis did break the law after murders occurred. He corralled his party into the limousine and told everyone to not cooperate with the investigation..."Lewis was not tried or accused of murder but he was found guilty of obstruction of justice and he testified against Lollar and Baker. No one was ever convicted for the crime but Lewis did reach an undisclosed settlement with the families of the victims in a civil case.

(sbnation.com) 